\title{
7. NEOGENE AND QUATERNARY CALCAREOUS NANNOPLANKTON FROM DSDP SITE 397 (NORTHWEST AFRICAN MARGIN)
}

\author{
Pavel Čepek, Federal Institute for Geosciences and Natural Resources \\ (Bundesanstalt für Geowissenschaften und Rohstoffe), Hannover, Federal Republic of Germany \\ and \\ Frank H. Wind, ${ }^{1}$ Department of Geology, Florida State University, Tallahassee, Florida
}

\section{INTRODUCTION}

DSDP Leg 47A recovered Tertiary sediments from two holes $(397,397 \mathrm{~A})$ from the eastern Atlantic Ocean adjacent to Cape Bojador $\left(26^{\circ} 50.7^{\prime} \mathrm{N}, 15^{\circ} 10.8^{\prime} \mathrm{W}\right)$. This site is northwest and downslope of DSDP Site 369 (Leg 41). Upper Cenozoic sediments were recovered in 102 cores from Hole 397, and down to the mid-point of Section 397A-34-1. The bathymetric and geographic location of Site 397 is shown in Figure 1. The ages, nannoplankton zonal assignment, and nannoplankton abundance and preservation in recovered cores are shown in Figure 2. Ages of the samples examined range from early Miocene (Discoaster druggi Zone - NN 2) through the top of the Quaternary (Emiliania huxleyi Zone - NN 21). Neogene and reworked Paleogene and Cretaceous species considered in this report are listed in Table 1.

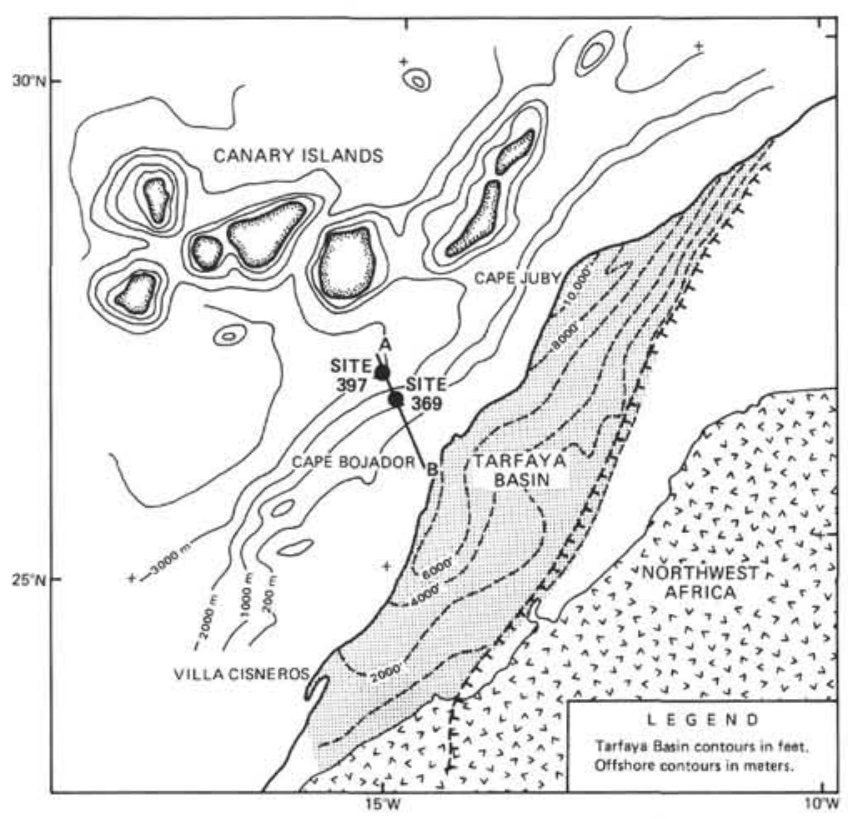

Figure 1. Topography near Site 397, showing location of Site 369 and sediment isopachs for onshore portion of the Tarfaya Basin.

\footnotetext{
'Present Address: Texaco Inc., Los Angeles, California.
}

The relative abundance of species in samples from late Pliocene through Quaternary is presented in Table 2 . The method utilized to express abundance is a modification of the technique outlined in Hay (1970), Gartner (1972), and Čepek (1978). When viewed on a light microscope at a magnification of $\times 1560$, a species represented by between 1 and 10 specimens per field of view of a standard smear slide is recorded as abundant (A); 1 specimen in 10 fields of view, common (C); 1 specimen in 50 fields of view, few $(\mathrm{F}) ; 1$ specimen in 200 fields of view, rare (R).

Zonal placement, quality of preservation, and abundance as recorded in Table 2 are based primarily upon light microscope examination of smear slides of ultrasonicated samples. Several well-preserved samples were studied with the scanning electron microscope, which was used to delineate the boundary between the Gephyrocapsa oceanica (NN 20) and Emiliania huxleyi (NN 21) zones. All scanning electron micrographs were taken on the AUTOSCAN of the Federal Institute for Geosciences and Natural Resources, Hannover, West Germany.

\section{CALCAREOUS NANNOPLANKTON BIOSTRATIGRAPHY AND ZONATION OF SITE 397}

Biostratigraphic zonations for the Pliocene and Quaternary have been proposed by Hay et al. (1967), Gartner (1969), Martini and Worsley (1970), Bukry and Bramlette (1970), Bukry (1971), Martini (1971), and Gartner (1977). The zonation used in this study is a combination of those proposed by Martini (1971) and Gartner (1977).

The discussion of nannoplankton biostratigraphy of the Neogene section at Site 397 is presented in two parts. Lower Miocene through lower Pliocene sediments are briefly surveyed. The reader is directed to Mazzell et al. (this volume) and Salvatorini and Cita (this volume) for more extensive analysis of the biostratigraphy of this interval, and in the latter reference, for a discussion of nannoplankton-planktonic foraminiferal biostratigraphy. The interval from the top of the lower Pliocene to the top of the Quaternary is discussed at greater length. The abundance, distribution, and quality of preservation of coccoliths in this younger portion of the recovered section is presented in Table 2. 


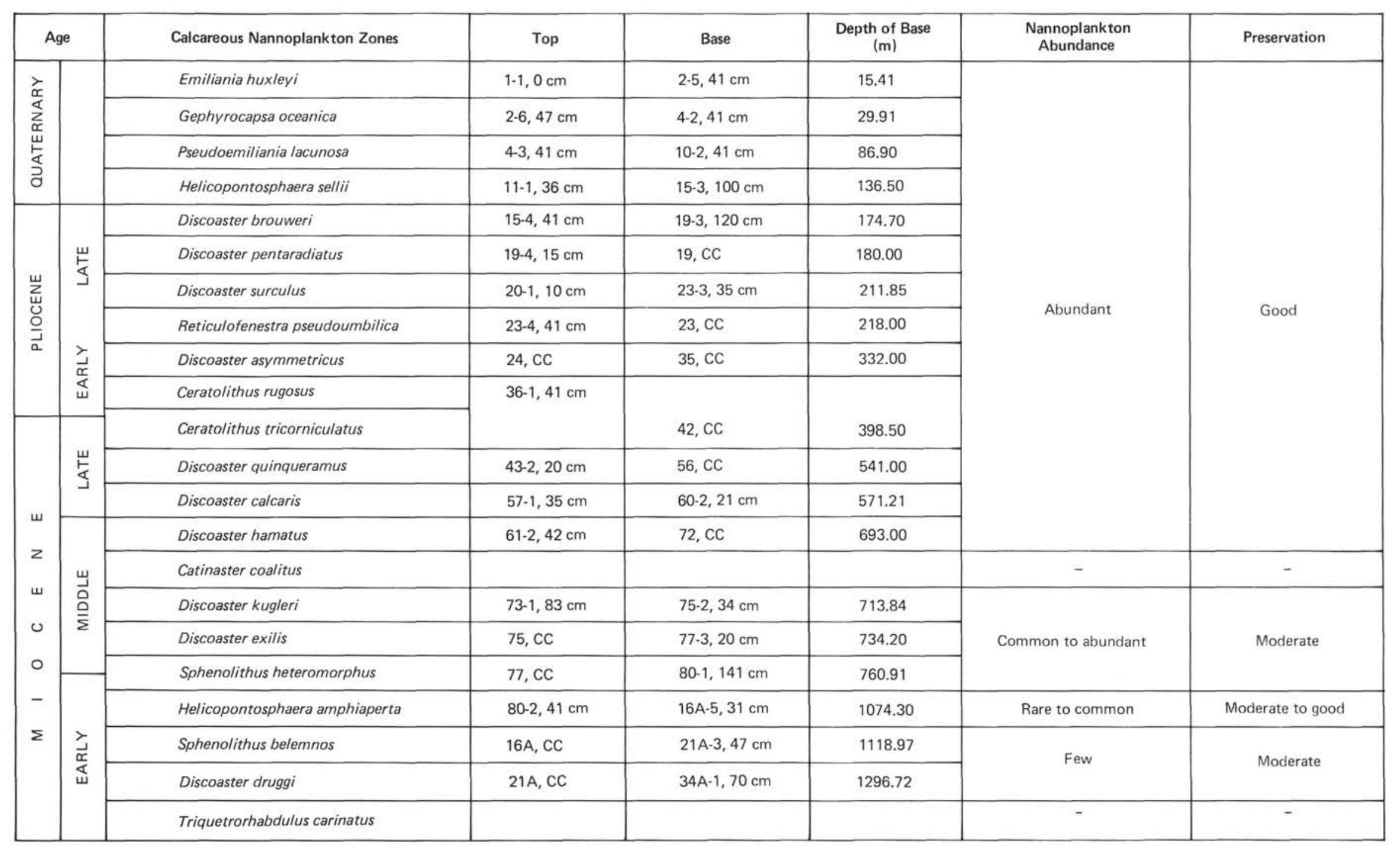

Figure 2. Age determinations, zonal assignment, nannoplankton abundance and preservation for the Quaternary and Neogene of Site 397. 
TABLE 1

Nannofossil Species Considered in This Report Listed Alphabetically According to Species Name

Cretaceous

Corollithion achylosum (Stover)

Tetralithus aculeus (Stradner)

Hayesites albianus Manivit

Chiastozygus amphipons (Bramlette and Martini)

Parhabdolithus angustus (Stradner)

Parhabdolithus asper (Stradner)

Watznaueria barnesae (Black)

Lithraphidites carniolensis Deflandre

Lucianorhabdus cayeuxi Deflandre

Nannoconus colomi (de Lapparent)

Prediscosphaera cretacea (Arkhangelsky)

Arkhangelskiella cymbiformis Vekshina

Micula decussata Vekshina

Zygodiscus diplogrammus (Deflandre and Fert)

Cribrosphaerella ehrenbergi (Arkhangelsky)

Corollithion exiguum Stradner

Eiffellithus eximius (Stover)

Reinhardtites fenestratus (Worsley)

Lithastrinus floralis Stradner

Marthasterites furcatus Deflandre

Parhabdolithus infinitus (Worsley)

Lucianorhabdus maleformis Reinhardt

Vagalapilla matalosa (Stover)

Gartnerago obliquum (Stradner)

Phanulithus obscurus (Deflandre)

Ahmuellerella octoradiata (Gorka)

Corollithion signum Stradner

Vagalapilla stradneri (Rood, Hay, and Barnard)

Eiffellithus trabeculatus (Gorka)

Eiffellithus turriseiffeli (Deflandre and Fert)

Cenozoic

Sphenolithus abies Deflandre

Pontosphaera alboranensis Bartolini

Helicopontosphaera ampliaperta (Bramlette and Wilcoxon)

Discolithina anisoternia Kamptner

Cyclolithella annulus (Cohen)

Scyphosphaera apsteinii Lohmann

Discoaster asymmetricus Gartner

Discoaster barbadiensis Tan Sin Hok

Sphenolithus belemnos Bramlette and Wilcoxon

Reticulofenestra bisecta (Hay, Mohler, and Wade)

Discoaster bollii Martini and Bramlette

Discoaster brouweri Tan Sin Hok

Discoaster calcaris Gartner

Gephyrocapsa californiensis Kamptner

Triquetrorhabdulus carinatus Martini

Discoaster challengeri Bramlette and Riedel

Rhabdosphaera clavigera Murray and Blackman

Cretarhabdus sp.

Ceratolithus cristatus Kamptner

Chiasmolithus danicus (Brotzen)

Discoaster deflandrei Bramlette and Riedel

Dictyococcites dictyodus (Deflandre and Fert)

Discoaster div. sp.

Pontosphaera discopora Schiller

Sphenolithus distentus (Martini)

Coccolithus doronicoides Black and Barnes

Discoaster druggi Bramlette and Wilcoxon

Discoaster exilis Martini and Bramlette

Cyclococcolithus formosus Kamptner

Scapholithus fossilis Deflandre

Oolithotus fragilis (Lohmann)

Discoaster hamatus Martini and Bramlette

Thoracosphaera heimi (Lohmann)

Sphenolithus belemnos Bramlette and Wilcoxon

Emiliania huxleyi (Lohmann)

Pontosphaera indooceanica Cepek
TABLE 1 - Continued

Discolithina japonica Takayama

Helicopontosphaera kamptneri Hay and Mohler

Discoaster kugleri Martini and Bramlette

Pseudoemiliania lacunosa (Kamptner)

Cyclococcolithus leptoporus (Murray and Blackman)

Ellipsolithus macellus (Bramlette and Sullivan)

Cyclococcolithus macintyeri Bukry and Bramlette

Umbilicosphaera mirabilis Lohmann

Sphenolithus moriformis (Brönnimann and Stradner)

Gephyrocapsa oceanica Kamptner

Coccolithus pelagicus (Wallich)

Discoaster pentaradiatus Tan Sin Hok

Reticulofenestra pseudoumbilica (Gartner)

Syracosphaera pulchra Lohmann

Discoaster quinqueramus Gartne

Coccolithus scissurus (Hay, Mohler, and Wade)

Scyphosphaera sp.

Helicopontosphaera sellii Bukry and Bramlette

Sphenolithus sp.

Aspidorhabdus stylifer (Lohmann)

Discoaster surculus Martini and Bramlette

Syracosphaera sp.

Thoracosphaera sp.

Amaurolithus tricorniculatus (Gartner)

Reticulofenestra umbilica (Levin)

Discoaster variabilis Martini and Bramlette

\section{Miocene}

The deepest Tertiary recovery at Site 397 is Sample 397A-34-1, $70 \mathrm{~cm}$, which is placed in the lower Miocene Discoaster druggi Zone (NN 2). This sample, as do many in immediately overlying cores, contains some reworked Cretaceous taxa, primarily species of $\mathrm{Watz}$ naueria. Sample 397A-34-1, $102 \mathrm{~cm}$ is the highest sample containing in-situ Early Cretaceous (Hauterivian) specimens. The 100 to $105 \mathrm{~m}$.y. hiatus between these two samples represents nondeposition or erosion of post-Hauterivian Mesozoic strata, Paleogene sediments, and those of the lowermost Miocene zone, the Triquetrorhabdulus carinatus Zone (NN 1).

\section{Discoaster druggi Zone (NN 2)}

Authors: Martini and Worsley (1970).

Definition: Interval from the first occurrence of Discoaster druggi Bramlette and Wilcoxon to the last occurrence of Triquetrorhabdulus carinatus Martini.

Age: Early Miocene.

Important common species: Triquetrorhabdulus carinatus, Discoaster druggi, and Helicopontosphaera kamptneri.

Remarks: This, the oldest Tertiary zone encountered at Site 397, is present in Samples 397A-34-1, $70 \mathrm{~cm}$ through 397A-21, CC.

\section{Sphenolithus belemnos Zone (NN 3)}

Authors: Bramlette and Wilcoxon (1967).

Definition: Interval from the last occurrence of Triquetrorhabdulus carinatus Martini to the last occurrence of Sphenolithus belemnos Bramlette and Wilcoxon.

Age: Early Miocene.

Important common species: Helicopontosphaera ampliaperta, H. kamptneri, Discoaster druggi, Sphenolithus heteromorphus, $S$. belemnos (less common). 


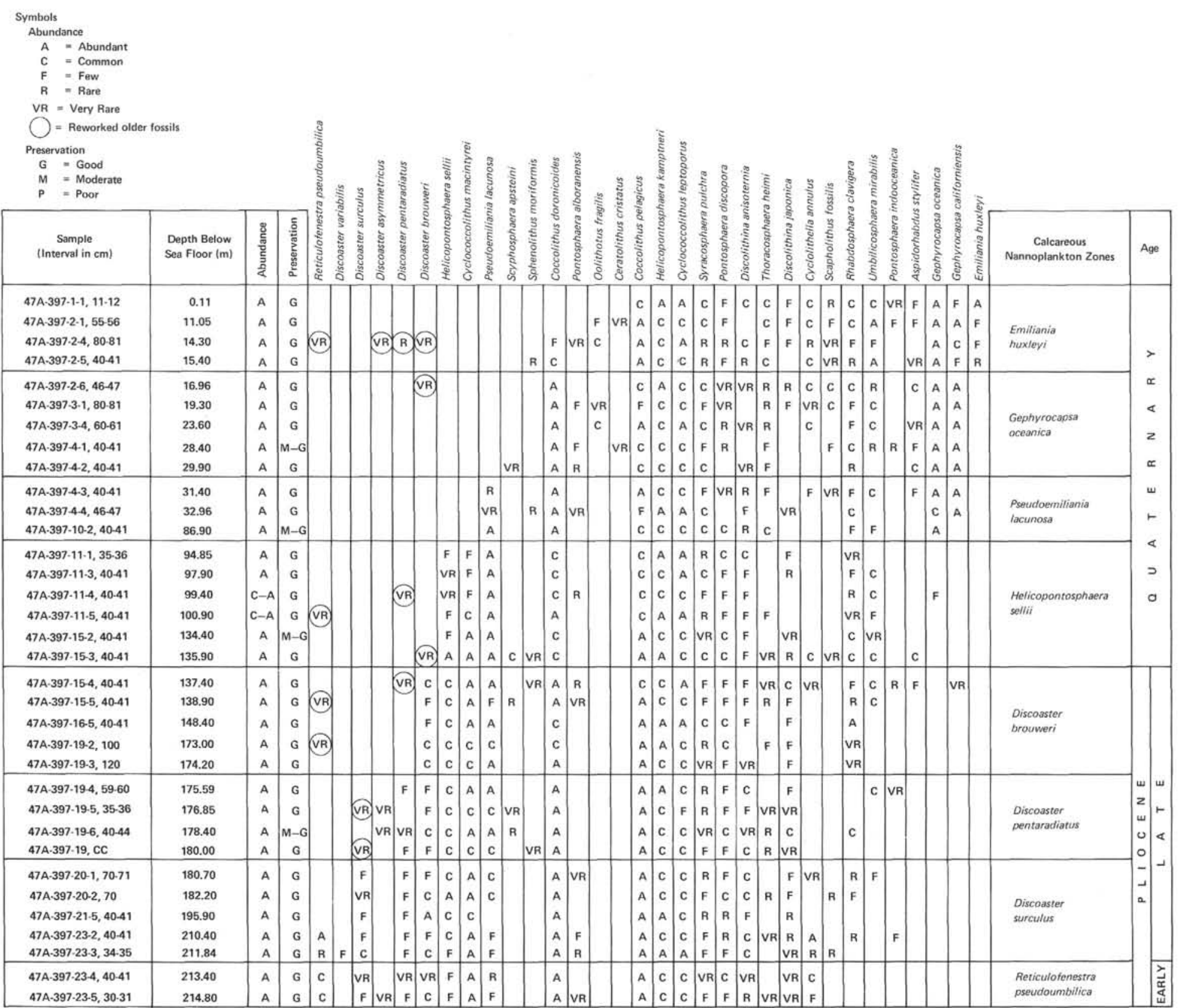


Remarks: This zone is represented by Samples 397A-21-3, $47 \mathrm{~cm}$ through 397A-16, CC.

\section{Helicopontosphaera ampliaperta Zone (NN 4)}

Authors: Bramlette and Wilcoxon (1967).

Definition: Interval from the last occurrence of Sphenolithus belemnos Bramlette and Wilcoxon to the last occurrence of Helicopontosphaera ampliaperta (Bramlette and Wilcoxon).

Age: Late early Miocene to early Middle Miocene.

Important common species: Helicopontosphaera ampliaperta, H. kamptneri, Sphenolithus heteromorphus.

Remarks: This zone is represented by the interval between Samples 397A-16-5, $31 \mathrm{~cm}$ and 397A-4, CC, and Samples 397-103, CC through 397-80-2, $41 \mathrm{~cm}$. Precise placement of the boundary between this zone and the preceding Sphenolithus belemnos Zone is subject to a degree of error due to the inherent inaccuracy in basing a zonal boundary on the last recorded occurrence of a poorly represented species.

\section{Sphenolithus heteromorphus Zone (NN 5)}

Authors: Bramlette and Wilcoxon (1967).

Definition: Interval from the last occurrence of Helicopontosphaera ampliaperta (Bramlette and Wilcoxon) to the last occurrence of Sphenolithus heteromorphus Deflandre.

Age: Middle Miocene.

Important common species: Sphenolithus heteromorphus, Discoaster exilis (less common).

Remarks: This zone is represented by the interval from Samples 397-80-1, $141 \mathrm{~cm}$ to $397-77$, CC.

\section{Discoaster exilis Zone (NN 6)}

Authors: Martini and Worsley (1970).

Definition: Interval from the last occurrence of Sphenolithus heteromorphus Deflandre to the first occurrence of Discoaster kugleri Martini and Bramlette.

Age: Middle Miocene.

Important common species: Discoaster exilis.

Remarks: The Discoaster exilis Zone is represented by Samples $397-77-3,20 \mathrm{~cm}$ to $397-75$, CC.

\section{Discoaster kugleri Zone (NN 7)}

Authors: Bramlette and Wilcoxon (1967).

Definition: Interval from the first occurrence of Discoaster kugleri Martini and Bramlette to the first occurrence of Catinaster coalitus Martini and Bramlette.

Age: Middle Miocene.

Important common species: Discoaster kugleri.

Remarks: The interval from Samples $397-75-2,34 \mathrm{~cm}$ to $397-73-1,83 \mathrm{~cm}$ is placed in this zone. The absence of the Catinaster coalitus Zone in overlying sediments prevents us from determining whether all or only part of the Discoaster kugleri Zone is present at this site.

The absence of nannofloras representing the Catinaster coalitus Zone (NN 8) and the early part of the Discoaster hamatus (NN 9) between Cores 72 and 73 indicates the presence of a hiatus at approximately 693 meters sub-bottom depth. This hiatus represents the nondeposition or erosion of approximately $0.7 \mathrm{~m} . \mathrm{y}$. of sedimentary history.

\section{Discoaster hamatus Zone (NN 9)}

Authors: Bramlette and Wilcoxon (1967).

Definition: Interval from the first to last occurrence of Discoaster hamatus Martini and Bramlette.

Age: Late middle Miocene to early late Miocene.

Important common species: Discoaster hamatus, $D$. bollii, $D$. pentaradiatus.

Remarks: The oldest samples from Hole 397 placed in this zone contain Discoaster bollii. This species has its first occurrence in the upper part of the Discoaster hamatus Zone, and its presence in the entire interval assigned to this zone suggests that the early part of this zone is missing from the Site 397 section. The upper portion of the Discoaster hamatus Zone is present in Samples 397-72, CC through 397-61-2, $42 \mathrm{~cm}$.

\section{Discoaster calcaris Zone (NN 10)}

Author: Martini (1969).

Definition: Interval from the last occurrence of Discoaster hamatus Martini and Bramlette to the first occurrence of Discoaster quinqueramus Gartner.

Age: Late Miocene.

Important common species: Discoaster calcaris, $D$. pentaradiatus.

Remarks: Many samples (397-60-2, $21 \mathrm{~cm}$ through $397-57-1,35 \mathrm{~cm}$ ) are typified by nannofloras of the Discoaster calcaris Zone. This interval is characterized by a series of slumped sections, with clasts and several seemingly undisturbed layers containing earlier Miocene and Late/Early Cretaceous nannofloras.

\section{Discoaster quinqueramus (Zone NN 11)}

Author: Gartner (1969).

Definition: Interval from the first to last occurrences of Discoaster quinqueramus Gartner.

Age: Late Miocene.

Important common species: Discoaster quinqueramus, $D$. pentaradiatus, $D$. calcaris, $D$. challengeri.

Remarks: This zone is present in Samples 397-56, CC through $397-43-2,20 \mathrm{~cm}$.

\section{Pliocene \\ Ceratolithus tricorniculatus and Ceratolithus rugosus Zones (NN 12-13)}

These two zones represent the interval from the last occurrence of Discoaster quinqueramus Gartner to the first occurrence of Discoaster asymmetricus Gartner.

Age: Latest late Miocene to early Pliocene.

Important common species: Reticulofenestra pseudoumbilica, Discoaster surculus, D. challengeri.

Remarks: Gartner (1969) proposed the first occurrence of Ceratolithus rugosus as the intervening datum for these two zones. Unfortunately, specimens of Ceratolithus and related genera are exceedingly rare in 
Site 397 samples and no specimens of $C$. rugosus were observed. These two zones are present in the interval from Samples 397-42, CC to $397-36-1,41 \mathrm{~cm}$.

\section{Discoaster asymmetricus Zone (NN 14)}

Author: Gartner (1969).

Definition: Interval from the first occurrence of Discoaster asymmetricus Gartner to the last occurrence of Amaurolithus tricorniculatus (Gartner).

Age: Early Pliocene.

Important common species: Discoaster asymmetricus, D. surculus, Reticulofenestra pseudoumbilica.

Remarks: Amaurolithus tricorniculatus is a rare nannofloral component. This zone is represented by Samples 397-35, CC through 397-24, CC.

\section{Reticulofenestra pseudoumbilica Zone (NN 15)}

Author: Gartner (1969).

Definition: Interval from the last occurrence of Amaurolithus tricorniculatus (Gartner) to the last occurrence of Reticulofenestra pseudoumbilica (Gartner).

Age: Late early Pliocene to earliest late Pliocene.

Important common species: Reticulofenestra pseudoumbilica, Discoaster asymmetricus, D. surculus, $D$. pentaradiatus.

Remarks: Two forms of Reticulofenestra pseudoumbilica are present in the Pliocene of Site 397. We place the top of this zone at the highest occurrence of large specimens of this species (generally $12 \mu \mathrm{m}$ diameter). Smaller forms, generally less than $8 \mu \mathrm{m}$ in diameter, persist higher in the section.

Coccoliths in the Reticulofenestra pseudoumbilica Zone (Samples 397-23, CC to 397-23-4, $41 \mathrm{~cm}$ ) are abundant and well preserved. Common species include Reticulofenestra pseudoumbilica, Cyclococcolithus macintyrei, Coccolithus doronicoides, C. pelagicus, Helicopontosphaera kamptneri, and Cyclococcolithus leptoporus.

\section{Discoaster surculus Zone (NN 16)}

Authors: Hay and Schmidt (1968) emend. Gartner (1969).

Definition: Interval from the last occurrence of Reticulofenestra pseudoumbilica (Gartner) to the last occurrence of Discoaster surculus Martini and Bramlette. Bramlette.

Age: Late Pliocene.

Important common species: Discoaster surculus.

Remarks: The base of this zone is placed at the last occurrence of large specimens of Reticulofenestra pseudoumbilica. Smaller specimens are present at the base of this zone in Samples 397-23-3, 34-35 cm; 397-23$2,40-41 \mathrm{~cm}$; and 397-23-1, 40-41 cm. Coccoliths in the Discoaster surculus Zone (Samples 397-23-3, 34-35 cm through 397-20-1, 70-71 cm) are abundant and well preserved. Common species include Discoaster surculus (which is present in all samples placed in this zone), Helicopontosphaera kamptneri, $H$. sellii (which is more common than in the preceding zone), Cyclococcolithus macintyrei, Coccolithus doronicoides, C. pelagicus, Cyclococcolithus leptoporus, and Discolithi- na anisoternia. Rhabdosphaera clavigera has its first occurrence in the lower part of this zone.

Martini (1971) indicates that the first occurrence of Pseudoemiliania lacunosa is in the lower part of the Discoaster surculus Zone (NN 16). At Site 397, however, rare to few specimens of $P$. lacunosa are present in samples as old as the upper part of the Reticulofenestra pseudoumbilica Zone (NN 15). Pseudoemiliania lacunosa becomes common to abundant in the middle portion of the Discoaster surculus Zone, and remains a dominant nannofloral component through the two succeeding Pliocene zones and the $P$. lacunosa Zone.

\section{Discoaster pentaradiatus Zone (NN 17)}

Authors: Martini and Worsley (1970).

Definition: Interval from the last occurrence of Discoaster surculus Martini and Bramlette to the last occurrence of Discoaster surculus Martini and Bramlette to the last occurrence of Discoaster pentaradiatus Tan Sin Hok.

Age: Late Pliocene.

Important common species: Helicopontosphaera sellii, Cyclococcolithus macintyrei, Discoaster brouweri, D. pentaradiatus (less common).

Remarks: Single fragmented specimens of Discoaster surculus were found in the two lowest samples placed in this zone (Samples 397-19, CC and 397-19-5, 35-36 cm). The presence of these specimens in these samples is viewed as the result of reworking or bioturbation. The coccoliths of this zone are abundant and generally well preserved. Common species include Helicopontosphaera sellii, H. kamptneri, Cyclococcolithus macintyrei, Pseudoemiliania lacunosa, Coccolithus doronicoides, C. pelagicus, and Cyclococcolithus leptoporus. This zone is represented by Samples 397-19, CC to $397-19-4,59-60 \mathrm{~cm}$.

\section{Discoaster brouweri Zone (NN 18)}

Authors: Hay and Schmidt (1968) emend. Martini and Worsley (1970).

Definition: Interval from the last occurrence of Discoaster pentaradiatus Tan Sin Hok to the last occurrence of Discoaster brouweri Tan Sin Hok.

Age: Late Pliocene.

Important common species: Discoaster brouweri.

Remarks: The top of this zone is placed above the highest "few" or "common" occurrence of Discoaster brouweri, which is not accompanied by other species of Discoaster. Rare specimens of $D$. brouweri are present in several Quaternary samples, occasionally accompanied by other reworked specimens, most noticeably, specimens of Discoaster surculus. The sharp difference in the abundance of $D$. brouweri between Samples $397-15-4,40-41 \mathrm{~cm}$ and $397-15-3,40-41 \mathrm{~cm}$ suggests that the shallower sample postdates the time of extinction of the discoasters, and the presence of $D$. brouweri in the latter sample is due to reworking. Coccoliths in the $D$. brouweri Zone (Samples 397-19-3, $120 \mathrm{~cm}$ through $397-15-4,40-41 \mathrm{~cm}$ ) are abundant and well preserved. Common species include Helicopontosphaera kampt- 
neri, H. sellii, Cyclococcolithus macintyrei, Pseudoemiliania lacunosa, Coccolithus doronicoides, C. pelagicus, and Cyclococcolithus leptoporus.

\section{Quaternary}

The zonation used for the Quaternary of Site 397 is a combination of the zonations proposed by Martini (1971) and Gartner (1977) (see Figure 3).

\section{Helicopontosphaera sellii Zone}

This zone is defined as the interval from the last ococcurrence of Helicopontosphaera sellii Bukry and Bramlette.

Bramlette.

Age: Early Quaternary.

Important common species: Helicopontosphaera sellii and Cyclococcolithus macintyrei.
Remarks: This zone is equivalent to the lower part of the Martini (1971) Pseudoemiliania lacunosa Zone (NN 19). Gartner (1977) divides the interval between the datums recognized here into two zones (Cyclococcolithus macintyrei and Helicopontosphaera sellii) which are separated by the last occurrence of Cyclococcolithus macintyrei. It is not possible to use this twofold division for this interval at Site 397, as both $C$. macintyrei and Helicopontosphaera sellii have their last occurrence in the same sample. The presence of a few specimens of Discoaster brouweri in the deepest sample placed in this zone is interpreted as the result of reworking.

Coccoliths of this zone are abundant and well preserved. Helicopontosphaera sellii and Cyclococcolithus macintyrei are abundant in the lower samples of this zone, but their abundance decreases in younger

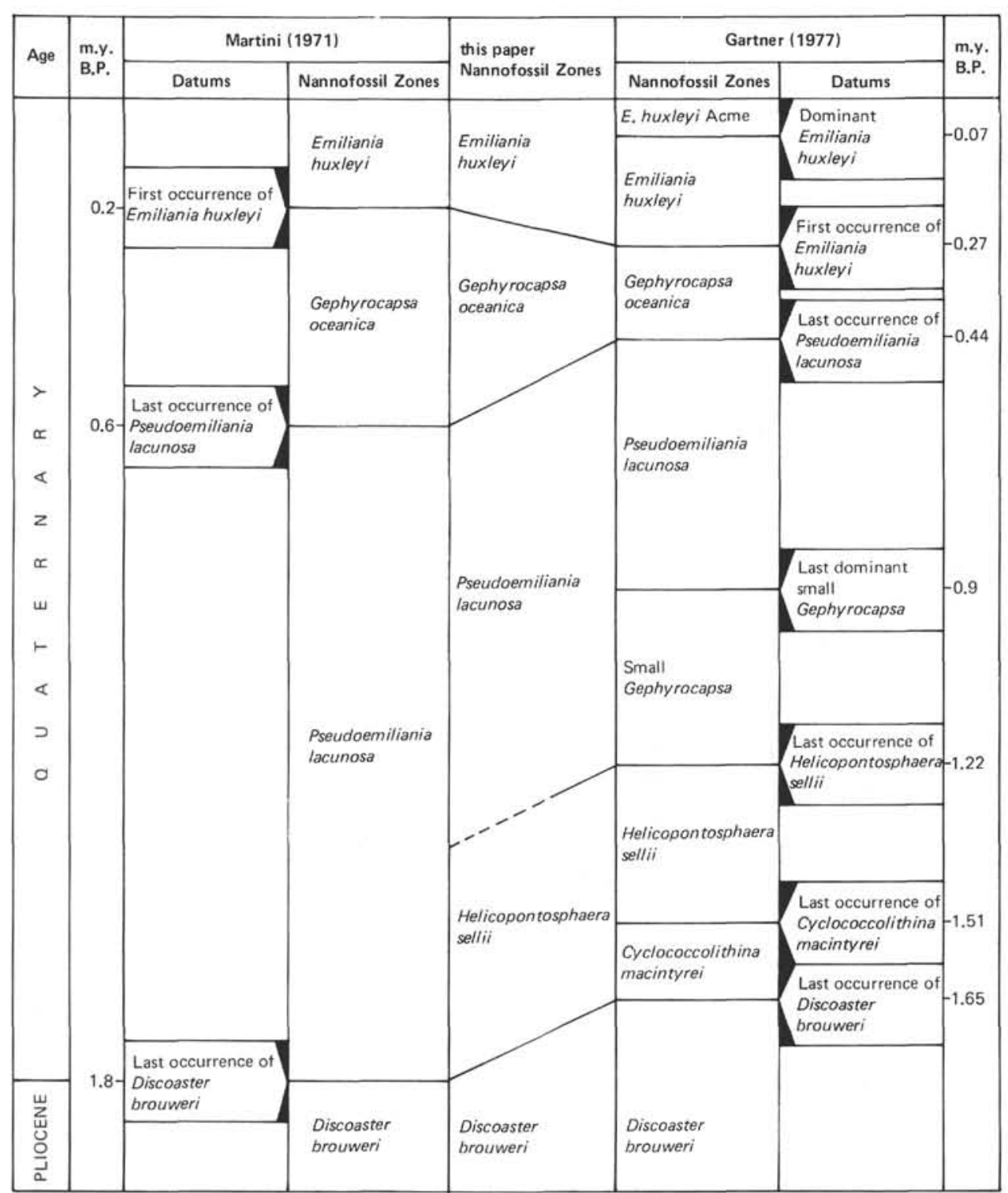

Figure 3. Upper Pliocene and Quaternary calcareous nannoplankton zonation. 
material. Coccolithus pelagicus also decreases in abundance up-section, but persists as an important nannofloral component. Gephyrocapsa oceanica has its first occurrence within this zone, in Sample 397-11-4, 40-41 cm. Pseudoemiliania lacunosa, Coccolithus doronicoides, Helicopontosphaera kamptneri, and Cyclococcolithus leptoporus are also common in samples from this zone, which is represented by the interval from Samples 397-15-3, 40-41 cm through 397-11-1, 35-36 cm.

\section{Pseudoemiliania lacunosa Zone}

This zone is defined as the interval from the last occurrence of Helicopontosphaera sellii Bukry and Bramlette and Cyclococcolithus macintyrei Bukry and Bramlette to the last occurrence of Pseudoemiliania lacunosa (Kamptner).

Age: Early Quaternary.

Important common species: Pseudoemiliania lacunosa, Gephyrocapsa oceanica, G. californiensis.

Remarks: Coccoliths of this zone are abundant and generally well preserved. Pseudoemiliania lacunosa is abundant in the lower part of this zone, but becomes rare in higher samples. The first occurrence of Gephyrocapsa californiensis falls within this zone, while $G$. oceanica is a continuous common element of the nannoflora. Additional common species include Coccolithus doronicoides, Helicopontosphaera kamptneri, Cyclococcolithus leptoporus, Syracosphaera pulchra, and Coccolithus pelagicus. The Pseudoemiliania lacunosa Zone is represented by the interval from Samples $397-10-2,40-41 \mathrm{~cm}$ through $397-4-3,40-41 \mathrm{~cm}$.

\section{Gephyrocapsa oceanica Zone}

Authors: Boudreaux and Hay (1967), emend. Gartner (1969).

Definition: Interval from the last occurrence of Pseudoemiliania lacunosa (Kamptner) to the first occurrence of Emiliania huxleyi (Lohmann).

Age: Late Quaternary.

Important common species: Gephyrocapsa oceanica and $G$. californiensis.

Remarks: The abundant and well-preserved coccolith assemblage of this zone is characterized by large numbers of Coccolithus doronicoides, C. pelagicus, Helicopontosphaera kamptneri, Cyclococcolithus leptoporus, Gephyrocapsa oceanica, and G. californiensis. This zone is represented in Hole 397 by Samples $397-4-2$, 40-41 cm through 397-2-6, 46-47 cm.

\section{Emiliania huxleyi Zone (NN 21)}

Authors: Boudreaux and Hay (1967).

Definition: Interval above the first occurrence of Emiliania huxleyi (Lohmann).

Age: Latest Quaternary.

Important common species: Emiliania huxleyi.

Remarks: The stratigraphic distribution and relative abundance of Emiliania huxleyi as presented in Table 2 is based upon scanning electron microscope analysis. Emiliania huxleyi is initially rare, but becomes more common in the youngest samples. Coccolithus pelagicus is generally more abundant in samples of this zone than in any previous Quaternary zone. The well-preserved nannoflora includes common to abundant specimens of Coccolithus pelagicus, Helicopontosphaera kamptneri, Cyclococcolithus leptoporus, Cyclolithella annulus, Gephyrocapsa oceanica, and Thoracosphaera heimi. The deepest sample placed in this zone is 397-2-5, 40-41 $\mathrm{cm}$.

\section{NANNOPLANKTON ABUNDANCE AND PRESERVATION}

Nannoplankton are generally well preserved and fairly abundant throughout most of the Neogene section recovered at Site 397 (see Figure 2). The lower Miocene sediments from Hole 397A often contain sparse and moderately well preserved nannofloras. As with most of the lower and middle Miocene populations from Holes 397 and 397A, discoasters appear to have been the forms most affected by the minor dissolution and reprecipitation evident in the majority of the samples. Nannofloras of the Helicopontosphaera ampliaperta Zone vary greatly in terms of population abundance and preservation because of the multiple bathymetric origin of sediment clasts and reworked nannoplankton. Similar variation in abundance and preservation typifies the intervals of slumps and debris flows in Core 397-57 through 397-61. The section above the slump sequence, from upper Miocene through the Quaternary, is consistently highly fossiliferous, with a diverse and wellpreserved calcareous nannoflora.

\section{SEDIMENTATION RATES FOR THE NEOGENE AT SITE 397}

The rate of sediment accumulation for the Neogene at Site 397 is exceptionally high for a hemipelagic environment, averaging approximately $65 \mathrm{~m} / \mathrm{m}$.y. A detailed sedimentation rate curve based upon the positions of nannoplankton zonal boundaries is presented in Figure 4. Absolute age corresponding to the biostratigraphic datums recognized at Site 397 are from Martini (1976, table 1).

The Sphenolithus belemnos and Helicopontosphaera ampliaperta zones (NN 3 and NN 4) of the upper Miocene are characterized by a sedimentation rate of approximately $180 \mathrm{~m} / \mathrm{m}$.y. These two zones are treated as a single unit because of the generally rare occurrence of Sphenolithus belemnos and the resulting poor reliability of its last occurrence datum as an accurate age indicator. Although both the top and base of the Helicopontosphaera ampliaperta Zone were not observed in a single hole at the site, the 313.4 meters of strata placed in this zone is probably an accurate representation of what would be recovered from a single hole, as Holes 397 and 397A were only 60 meters apart.

During the latter part of the early Miocene to the middle part of the middle Miocene (Sphenolithus heteromorphus Zone to Discoaster kugleri Zone) (Sections $397-81-1$ to $397-73-1$ ), the rate of deposition slowed to $15 \mathrm{~m} / \mathrm{m}$.y. The hiatus in the middle Miocene between Zones NN 7 and NN 9 is of approximately one m.y. duration. 


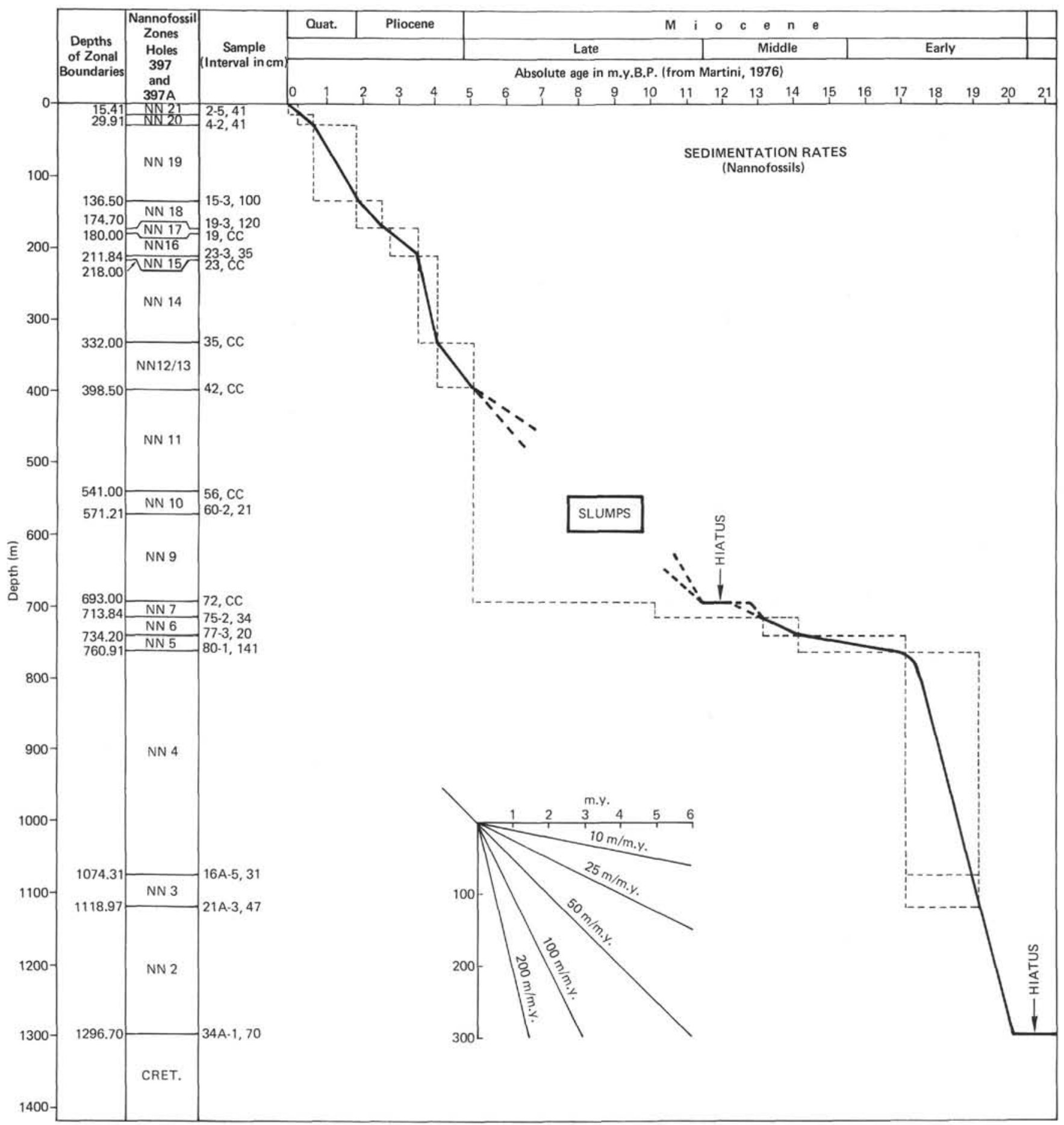

Figure 4. Rates of deposition for Site 397 based upon calcareous nannoplankton datums. Absolute ages are from Martini (1976). 
Much of the sediment in the upper Miocene section (Cores 397-72 to 397-43), from the Discoaster hamatus Zone to the Discoaster quinqueramus Zone, consists of slumped sediments. Therefore, an accurate determination of the depositional rate for autochthonous sediments is difficult. Inclusion of the slumped portions generate a sedimentation rate of approximately 50 $\mathrm{m} / \mathrm{m} . \mathrm{y}$.

Pliocene hemipelagic sediments accumulated at this site at an average rate of $83 \mathrm{~m} / \mathrm{m}$.y. A similar depositional rate persisted early in the Quaternary, but in the last 600,000 years, the rate slowed to approximately 50 $\mathrm{m} / \mathrm{m} . \mathrm{y}$.

\section{REWORKED NANNOPLANKTON}

One feature of sedimentation in the region of Site 397 during the Neogene was the almost continual rain of reworked earlier Tertiary and Cretaceous nannoplankton. Reworked Cretaceous specimens are often well preserved, as illustrated by the Cretaceous specimens shown in Plates 4 and 7 . Although clearly detectable when taxa are reworked into sediments of an age outside their documented stratigraphic range, redeposition of nearly contemporaneous sediments at Site 397 may help explain the great thickness of Neogene sediments observed in the region of Cape Bojador. Redeposition of nannoplankton continued into the Quaternary, as extended examination of samples from the youngest cores from this site occasionally reveals discoasters and Mesozoic species. Reworked species, their recognized range, and the cores in which they have been observed are listed in Figure 5. The occurrences listed only record those instances in which specimens were redeposited as discrete sedimentary particles rather than as part of a lithic clast in debris flows or slumps.

The lower and lower/middle Miocene at Site 397 is interpreted as a rapidly deposited, mostly allochthonous sequence of debris flows, turbid layer sediments, and slumped masses which were deposited following the erosion of post-Hauterivian Mesozoic and Paleogene sediments. Much of the lower Miocene at Site 397 consists of pebbly mudstones. The matrix in Cores 397A-33 through $397 \mathrm{~A}-16$ is dated as NN 2 to NN 3 , but contains common reworked specimens from the Oligocene and rarer Cretaceous specimens. Clasts from Cores 397A-16 and 397 A- 20 contain moderately well preserved upper Albian to Cenomanian nannofloras.

Cores 397-89 and 397-87 are chaotic breccia conglomerates consisting of dark brown, dark green, black, and tan pebbles in a dark olive-green matrix which is dated as the Helicopontosphaera ampliaperta Zone (NN 4). Clasts from Core 397-89 are either the same age as the matrix, or Cretaceous. A flaggy dark gray-green mudstone clast in Sample 397-89-2, 12-13 cm contains a well-preserved, diverse nannoflora which is dated as Coniacian to early Santonian based on the presence of Marthasterites furcatus, Eiffellithus eximius, Lithastrinus floralis, Corollithion exiguum, and C. signum. A tan limestone chip in Sample 397-89-2, 20 cm contains a poorly preserved nannoflora which can only be dated as no older than Turonian, based on the presence of Micula decussata and Cribrosphaerella ehrenbergi.

Core 397-87 contains a chaotic breccia conglomerate with nearly all clasts containing essentially contemporaneous nannofloras. However, one thin tan mudstone chip in Sample 397-87-3, $137 \mathrm{~cm}$ contains a moderately well-preserved nannoflora which, based on the concurrence of Corollithion achylosum, C. exiguum, Eiffellithus eximius, and Lithastrinus floralis, is dated as Turonian.

Core 397-57 also contains evidence of large-scale sediment reworking, but here, in the form of slumped intervals which are lithic clast-bearing marly nannofossil chalks and mudstones. Many clasts within these slumps contain Cretaceous nannofloras which are as abundant and well preserved as the richest samples from the Hauterivian section recovered in Hole 397A. Three dark gray-green mudstones from Sections 57-4 and 57-5 are approximately the same age; the presence of Lithastrinus floralis, Corollithion achylosum, Hayesites albianus, Parhabdolithus infinitus, P. asper, Reinhardtites fenestratus, and Eiffellithus trabeculatus indicates an Albian age. Slight differences in the populations of the individual clasts suggest that one clast is early Albian, while the others are probably late Albian.

\section{ACKNOWLEDGMENTS}

We thank Mr. E. Knickrem for operating the scanning electron microscope. Primary support was provided in part by the Deutsche Forschungsgemeinschaft and BGR. We thank Dr. Bilal ul Haq (Woods Hole) for reviewing the manuscript.

\section{REFERENCES}

Boudreaux, J. E. and Hay, W. W., 1967. Calcareous nannoplankton and biostratigraphy of the Late PliocenePleistocene-Recent sediments in the submarex cores, Revista Espanola de Micropaleontologia, v. 1, p. 249-292.

Bramlette, M. N. and Wilcoxon, J. A., 1967. Middle Tertiary calcareous nannoplankton of the Cipero section, Trinidad, W. I., Tulane Stud. Geol., v. 5, p. 93-132.

Bukry, D., 1971. Coccolith stratigraphy Leg 7, Deep Sea Drilling Project. In Winterer, E. L., Riedel, W.R., et al., Initial Reports of the Deep Sea Drilling Project, v.7, Part 2: Washington (U.S. Government Printing Office), p. 15131528.

Bukry, D. and Bramlette, M. N., 1970. Coccolith age determinations, Leg 3 Deep Sea Drilling Project. In Maxwell, A. E., et al., Initial Reports of the Deep Sea Drilling Project v. 3: Washington (U.S. Government Printing Office), p. 589-611.

Cepek, P., 1978. Mesozoic calcareous nannoplankton of the eastern North Atlantic, Leg 41. In Seibold, E., Lancelot, Y., et al., Initial Reports of the Deep Sea Drilling Project, v. 41: Washington (U.S. Government Printing Office), p. 667-687.

Gartner, S., 1969. Correlation of Neogene planktonic foraminifer and calcareous nannofossil zones, Gulf Coast Assoc. Geol. Soc. Trans., v. 19, p. 585-599.

1972. Late Pleistocene calcareous nannofossils in the Caribbean and their interoceanic correlation, Paleogeogr., Paleoclimatol., Paleoecol., v. 12, p. 169-191. 


\begin{tabular}{|c|c|c|c|c|}
\hline SPECIES NAME & KNOW & ANGE & $\begin{array}{c}\text { HOLE } \\
397 \\
\text { Core No. }\end{array}$ & $\begin{array}{c}\text { HOLE } \\
397 A \\
\text { Core No. }\end{array}$ \\
\hline Tetralithus aculeus (Stradner) & Late Campanian & - Late Maestrichtian & 4 & \\
\hline Chiastozygus amphipons (Bramelette and Martini) & Turonian & - Late Maestrichtian & 4 & \\
\hline Parhabdolithus angustus (Stradner) & Late Aptian & - Campanian & 4 & 19 \\
\hline Parhabdolithus asper (Stradner) & Early Berriasian & - Late Turonian & & 15 \\
\hline Discoaster asymmetricus Gartner & Early Pliocene & - Late Pliocene & 2,13 & \\
\hline Discoaster barbadiensis Tan Sin Hok & Early Eocene & - Late Eocene & 33 & \\
\hline Watznaueria barnesae (Black) & Oxfordian & - Danian & $4,87,89,95,102$ & $10,19,20,32,33$ \\
\hline Sphenolithus belemnos Bramlette and Wilcoxon & Early Miocene & & 75 & \\
\hline Reticulofenestra bisecta (Hay, Mohler, and Wade) & Eocene & - Oligocene & & 32 \\
\hline Discoaster bollii Martini and Bramlette & Middle Miocene & - Late Miocene & 34 & \\
\hline Discoaster brouweri Tan Sin Hok & Middle Miocene & - Late Pliocene & $2,12,13,15$ & \\
\hline Discoaster calcaris Gartner & Middle Mioçene & - Late Miocene & $10,11,12$ & \\
\hline Triquetrorhabdulus carinatus Martini & Late Oligocene & - Early Miocene & 74 & \\
\hline Lithraphidites carniolensis Deflandre & Early Berriasian & - Late Maestrichtian & 4 & \\
\hline Lucianorhabdus cayeuxi Deflandre & Early Turonian & - Late Maestrichtian & 4 & \\
\hline Discoaster challengeri Bramlette and Riedel & Middle Miocene & - Late Pliocene & 16,19 & \\
\hline Nannoconus colomi (de Lapparent) & Late Tithonian & - Early Barremian & 83 & \\
\hline Prediscosphaera cretacea (Arkhangelsky) & Middle Cenomanian & - Late Maestrichtian & $2,4,10,19,20,21$ & \\
\hline Arkhangelskiella cymbiformis Vekshina & Campanian & - Maestrichtian & 4 & \\
\hline Micula decussata Vekshina & Late Cretaceous & & 87 & 6 \\
\hline Dictyococcites dictyodus (Deflandre and Fert) & Middle Eocene & - Early Miocene & 71,76 & 16 \\
\hline Zygodiscus diplogrammus (Deflandre and Fert) & Late Valanginian & - Maestrichtian & $4,10,87$ & 10,16 \\
\hline Sphenolithus distentus (Martini) & Middle Oligocene & - Late Oligocene & & 16 \\
\hline Discoaster druggi Bramlette and Wilcoxon & Early Miocene & - Middle Miocene & 34 & \\
\hline Cribrosphaerella ehrenbergi (Arkhangelsky) & Late Albian & - Maestrichtian & 4 & 7 \\
\hline Eiffellithus sp. & Cretaceous & & 97 & \\
\hline Discoaster exilis Martini and Bramlette & Early Miocene & - Middle Miocene & 1,9 & \\
\hline Eiffellithus eximius (Stover) & Cenomanian & - Maestrichtian & $4,87,89$ & \\
\hline Lithastrinus floralis Stradner & Late Aptian & - Early Santonian & 4 & 19 \\
\hline Marthasterites furcatus Deflandre & Early Coniacian & Early Campanian & 38,53 & \\
\hline Ellipsolithus macellus (Bramlette and Sullivan) & Early Paleocene & - Early Eocene & 34 & \\
\hline Lucianorhalodus maleformis Reinhardt & Late Turonian & - Early Campanian & 4 & \\
\hline Vagalapilla matalosa (Stover) & Middle Aptian & - Early Turonian & 2,19 & \\
\hline Micula sp. & Late Cretaceous & & 4 & \\
\hline Nannoconus sp. & Tithonian & - Cretaceous & 80,87 & \\
\hline Gartnerago obliguum (Stradner) & Cenomanian & - Maestrichtian & 4 & \\
\hline Phanulithus obscurus (Deflandre) & Early Coniacian & - Late Maestrichtian & & 19 \\
\hline Ahmuellerella octoradiata (Gorka) & Middle Turonian & - Maestrichtian & 4,87 & \\
\hline Parhabdolithus sp. & Cretaceous & & & 33 \\
\hline Helicopontosphaera paraliela (Bramlette and Wilcoxon) & Oligocene & - Early Miocene & 72 & \\
\hline Discoaster pentaradiatus Tan Sin Hok & Middle Miocene & - Late Pliocene & $2,11,15,16$ & \\
\hline Sphenolithus predistentus Bramlette and Wilcoxon & Late Eocene & - Oligocene & & 16 \\
\hline Reticulogenestra pseudoumbilica (Gartner) & Late Miocene & - Early Pliocene & $2,11,15,19$ & \\
\hline Discoaster saipanensis Bramlette and Riedel & Middle Eocene & - Late Eocene & 33 & \\
\hline Helicopontosphaera seminulum (Bramlette and Sullivan) & Early Eocene & - Middle Eocene & & 16 \\
\hline Discoaster surculus Martini and Bramlette & Late Miocene & - Late Pliocene & $10,11,12,19$ & \\
\hline Vagalapillia stradneri (Rood, Hay, and Barnard) & Late Oxfordian & - Maestrichtian & 4 & 20 \\
\hline Tetralithus sp. & Cretaceous & & & 6 \\
\hline Eiffellithus trabeculatus (Gorka) & Middle Albian & - Maes:richtian & 19 & \\
\hline Tetralithus sp. & Cretaceous & & & 6 \\
\hline Marthasterites tribrachiatus (Bramlette and Riedel) & Early Eocene & & $33,42,61,62$ & \\
\hline Eiffellithus turriseiffeli (Deflandre and Fert) & Late Albian & - Late Maestrichtian & $4,5,13,16,19,80,83,87,89$ & 16 \\
\hline Discoaster variabilis Martini and Bramlette & Early Miocene & - Late Pliocene & 13 & \\
\hline Zygodiscus sp. & Cretaceous & & & 33 \\
\hline
\end{tabular}

Figure 5. Reworked calcareous nannoplankton at Site 397. 
1973. Absolute chronology of the Late Neogene clacarous nannofossil succession in the equatorial Pacific, Geol. Soc. Am. Bull., v. 84, p. 2021-2033.

1977. Calcareous nannofossil biostratigraphy and revised zonation of the Pleistocene, Marine Micropaleont., v. 2 , p. $1-25$.

Hay, W. W., 1970. Calcareous nannofossils from cores recovered on Leg 4. In Bader, R. G., Gerard, R. D., et al., Initial Reports of the Deep Sea Drilling Project, v. 4: Washington (U. S. Government Printing Office), p. 455-503.

Hay, W. W. and Schmidt, R. R., 1968. Calcareous nannofossils in the Pliocene of Italy, Giornale di Geologia, v. 32 , p. $153-161$.

Hay, W. W., Mohler, H., Roth, P. H., Schmidt, R. R., and Boudreaux, J. E., 1967. Calcareous nannoplankton zonation of the Cenozoic of the Gulf Coast and CaribbeanAntillean area, and transoceanic correlations, Gulf Coast Assoc. Geol. Soc. Trans., v. 17, p. 428-480.
Martini, E., 1965. Mid-Tertiary calcareous nannoplankton from Pacific deep-sea cores. In Whittary, W. F. and Bradshaw, R. B. (Eds.), Submarine geology and geophysics: Proc. 17th Symp. Colston Res. Soc., p. 393-411. 1969. Nannoplankton aus dem Miozan von Gabon (Westafrika), N. jb. Geol. Palaont. Abh., v. 132, p. 285-300.

1971. Standard Tertiary calcareous nannoplankton zonation. In Farinacci, A. (Ed.), Second Plankt. Conf. Proc., Roma 1970, p. 739-785.

1976. Cretaceous to Recent nannoplankton from the central Pacific Ocean (DSDP Leg 33). In Schlanger, S. O., Jackson, E. D., et al., Initial Reports of the Deep Sea Drilling Project, v. 33: Washington (U.S. Government Printing Office), p. 383-424.

Martini, E. and Worsley, T., 1970. Standard Neogene calcareous nannoplankton zonation, Nature, v. 225, p. 289. 



\section{PLATE 1}

All specimens approximately $\times 2800$.

Figure 1 Umbilicosphaera mirabilis Lohmann. Distal side. Sample 397-2-1, 55-56 cm.

1a. Phase contrast.

1b. Cross-polarized light.

Figure 2 Pseudoemiliania lacunosa (Kamptner). Distal side. Sample 397-11-1, 35-36 cm.

2a. Phase contrast.

2b. Cross-polarized light.

Figure 3

Coccolithus doronicoides Black and Barnes. Distal side. Sample 397-2-6, 46-47 cm.

3a. Phase contrast.

3b. Cross-polarized light.

3c. Cross-polarized $+45^{\circ}$.

Figure $4 \quad$ Scapholithus fossilis Deflandre. Sample 397-4-4, $46-47 \mathrm{~cm}$.

4a. Phase contrast.

4b. Cross-polarized light.

4c. Cross-polarized light $+45^{\circ}$.

Figure $5 \quad$ Cyclolithella annula (Cohen). Distal side. Sample $397-2-6,46-47 \mathrm{~cm}$.

5a. Phase contrast.

5b. Cross-polarized light.

Figure 6 Syracosphaera pulchra Lohmann. Distal side. Sample 397-2-1, 55-56 cm.

6a. Phase contrast.

6b. Cross-polarized light.

6c. Cross-polarized light $+45^{\circ}$.

Figure 7 Gephyrocapsa oceanica Kamptner. Distal side. Sample 397-2-1, 55-56 cm.

7a. Phase contrast.

7b. Cross-polarized light.

7c. Cross-polarized light $+45^{\circ}$.

Figure $8 \quad$ Helicopontosphaera sellii Bukry and Bramlette.

Distal side. Sample 397-19-5, 35-36 cm.

8a. Phase contrast.

8b. Cross-polarized light.

8c. Cross-polarized light $+45^{\circ}$.

Figure 9 Helicopontosphaera kamptneri Hay and Mohler. Distal side. Sample 397-2-4, 80-81 cm.

9a. Phase contrast.

9b. Cross-polarized light.

9c. Cross-polarized light $+45^{\circ}$.

Figure 10 Cyclococcolithus macintyrei Bukry and Bramlette. Distal side of the distal shield. Sample $397-20-2,70 \mathrm{~cm}$.

10a. Phase contrast.

10b. Cross-polarized light. 
PLATE 1

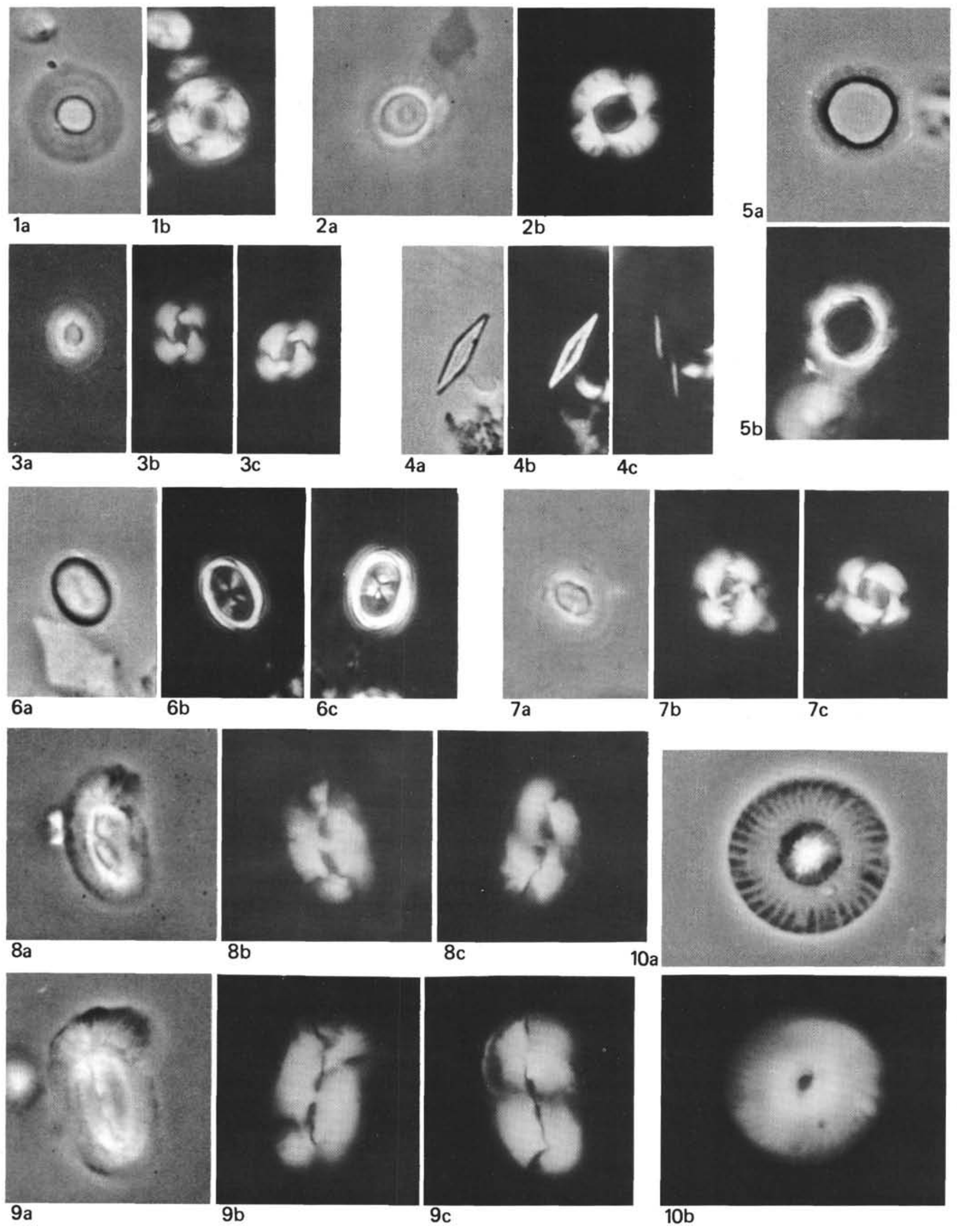


PLATE 2

All specimens approximately $\times 2800$.

Figure 1 Discoaster asymmetricus Gartner. Distal side. Sample 397-19-19-5, 35-36 cm. Phase contrast.

Figure 2 Discoaster surculus Martini and Bramlette. Proximal side. Sample 397-23-2, 40-41 cm. Phase contrast.

Figure 3 Discoaster pentaradiatus Tan Sin Hok. Proximal side. Sample 397-20-2, $70 \mathrm{~cm}$. Phase contrast.

Figure 4 Rhabdosphaera clavigera Murray and Blackmann. Sample 397-2-1, 55-56 cm.

4 a. Phase contrast.

4b. Cross-polarized light.

Figure $5 \quad$ Ceratolithus cristatus Kamptner. Sample 39723-5, 30-31 cm.

5a. Phase contrast.

5b. Cross-polarized light.

5c. Cross-polarized light $+45^{\circ}$.

Figure 6 Discoaster brouweri Tan Sin Hok. Distal side. Sample 397-19-2, $100 \mathrm{~cm}$. Phase contrast.

Phase contrast.

Figure 7 Coccolithus pelagicus (Wallich). Distal side. Left - without bridge; right - with bridge. Sample 397$2-1,40-41 \mathrm{~cm}$.

7a. Phase contrast.

7b. Cross-polarized light.

7c. Cross-polarized light $+45^{\circ}$. 


\section{PLATE 2}
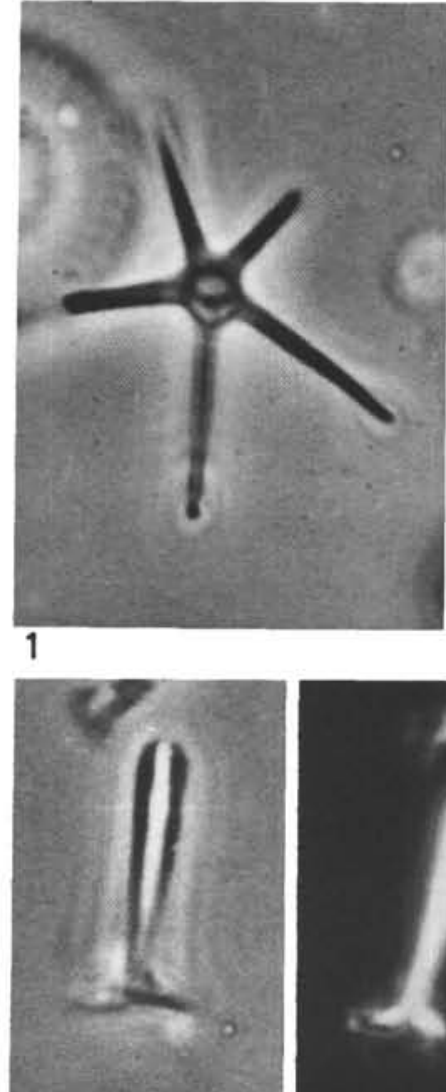

$4 a$

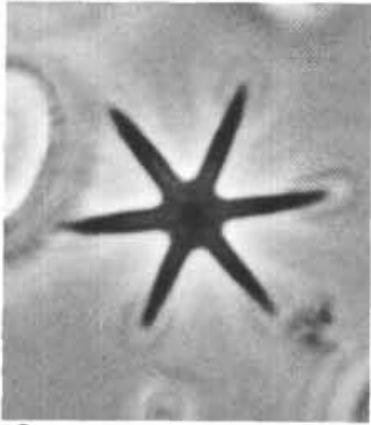

$6 a$

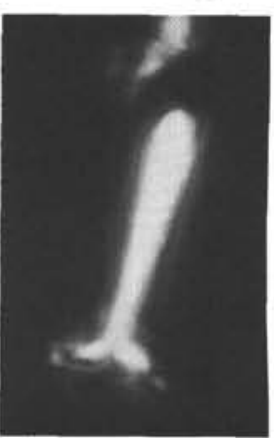

$4 b$

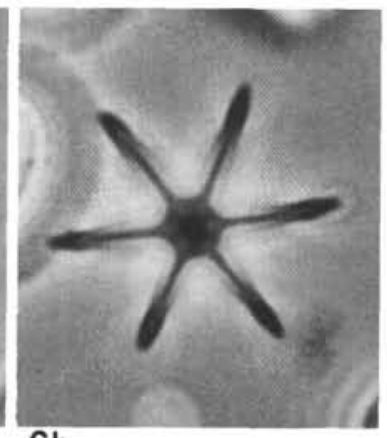

$6 b$

$5 a$

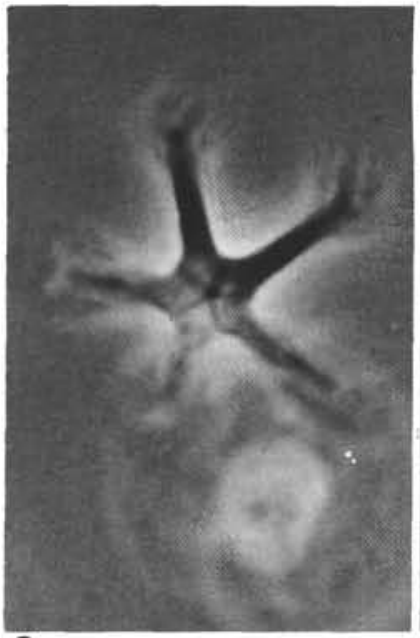

3a

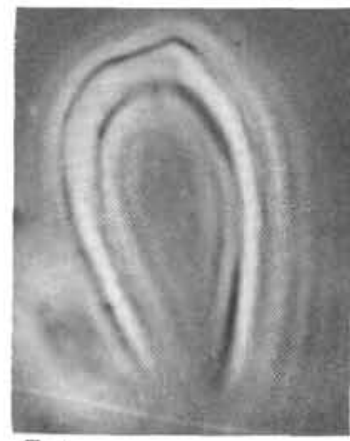

$5 b$
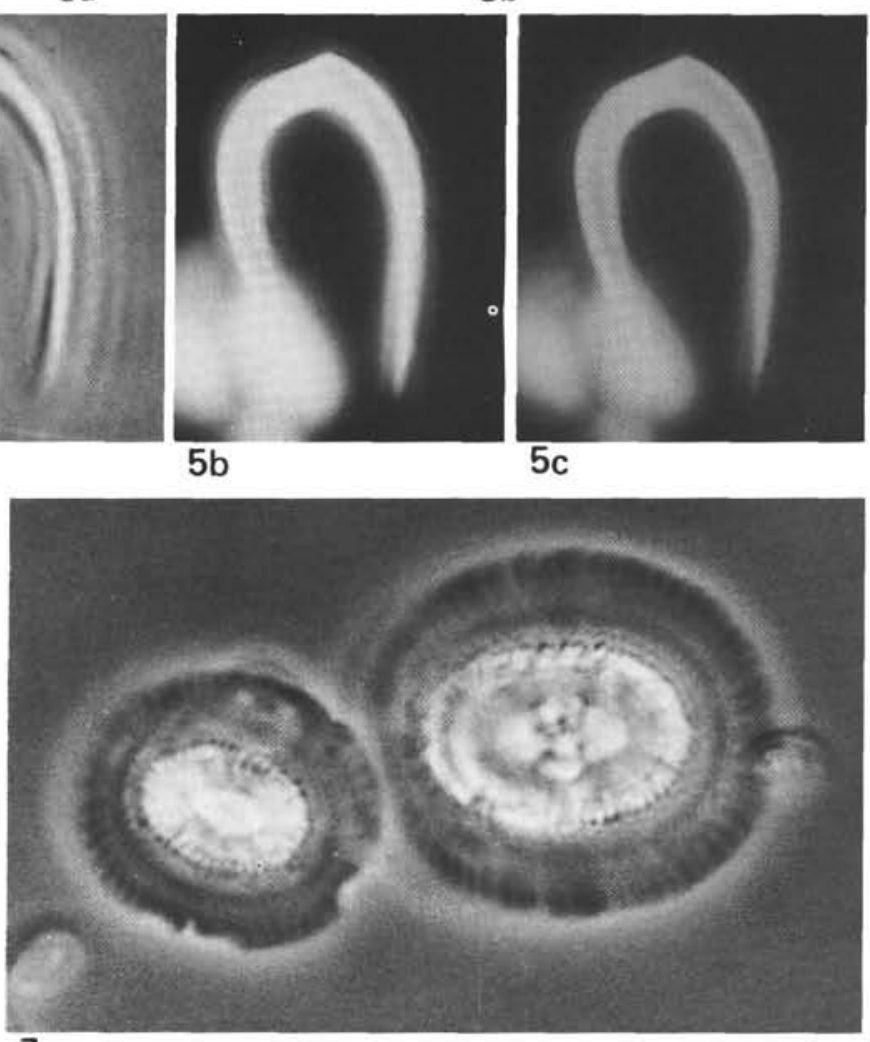

$7 a$

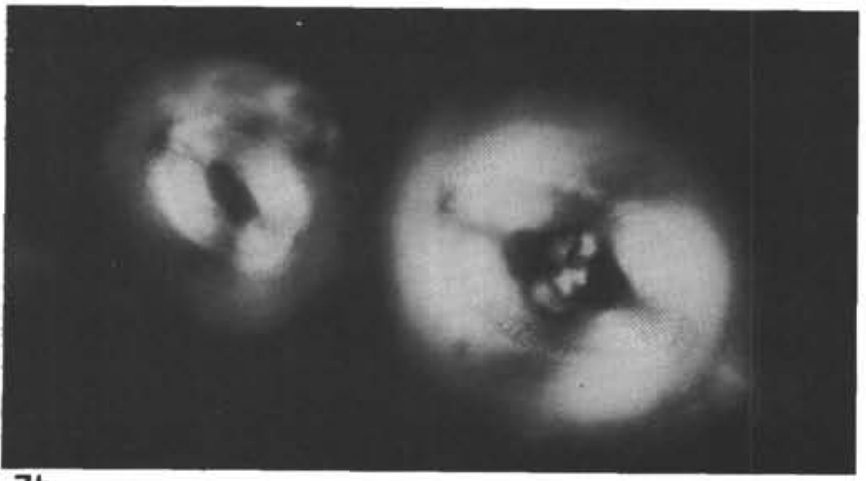

$7 b$

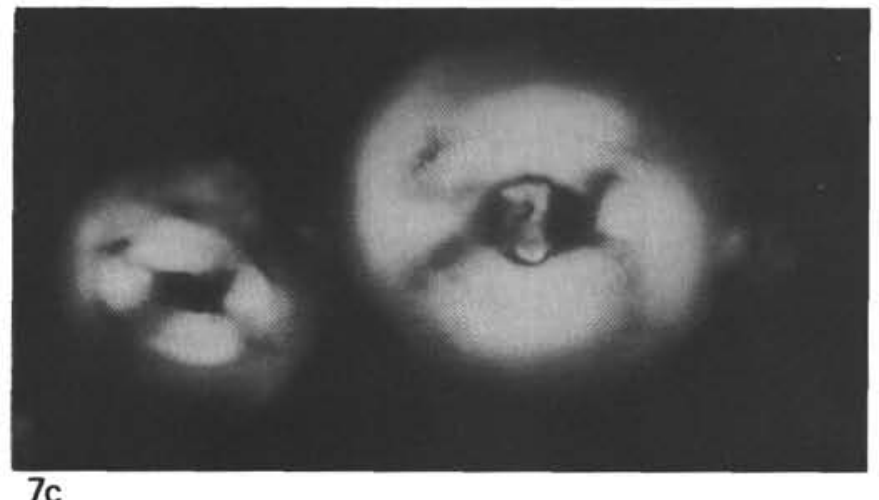




\section{PLATE 3}

All specimens approximately $\times 2800$.

Figure $1 \quad$ Pontosphaera indooceanica Čepek. Distal side. Sample 397-2-1, 55-56 cm.

1a. Phase contrast.

1b. Cross-polarized light.

1c. Cross-polarized light $+45^{\circ}$.

Figure 2 Discolithina anisotrenia Kamptner. Distal side. Sample 397-10-2, 40-41 cm.

2a. Phase contrast.

2b. Cross-polarized light.

2c. Cross-polarized light $+45^{\circ}$.

Figure 3 Cyclococcolithus leptoporus (Murray and Blackmann) Distal side. Sample 397-2-4, 80-81 cm.

3a. Phase contrast.

3b. Cross-polarized light.

Figure 4 Thoracosphaera heimi (Lohmann). Sample 397-1-1, 11-12 cm.

4a. Phase contrast.

4b. Cross-polarized light.

4c. Fragment; phase contrast.

4d. Fragment; cross-polarized light.

Figure $5 \quad$ Reticulofenestra pseudoumbilica (Gartner). Distal side. Sample 397-8-4, 39-40 cm (reworked).

5a. Phase contrast.

5b. Cross-polarized light.

5c. Cross-polarized light $+45^{\circ}$. 
PLATE 3
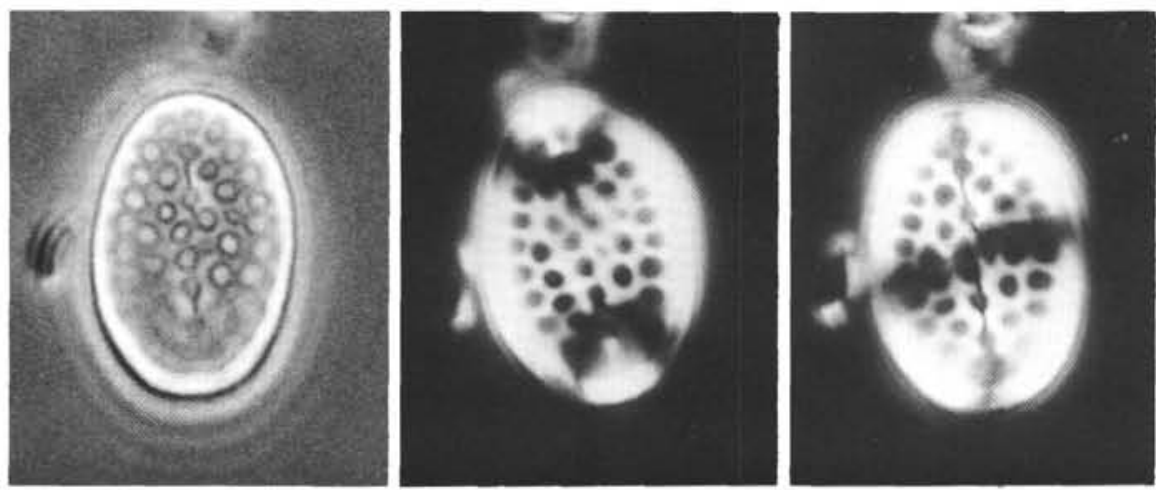

1a

$1 b$

1c
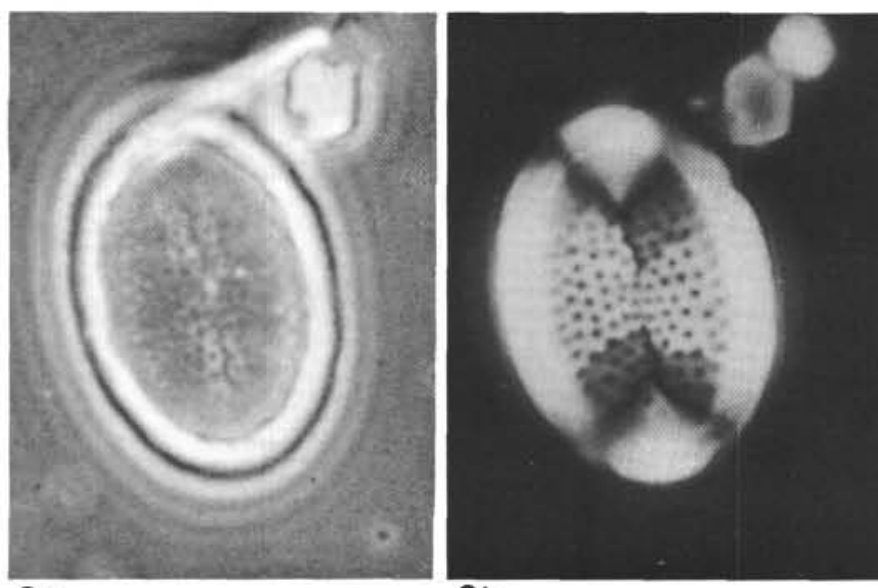

2a

$2 b$

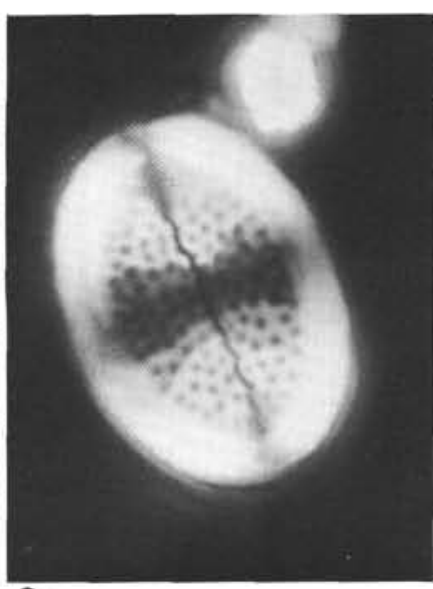

$3 a$

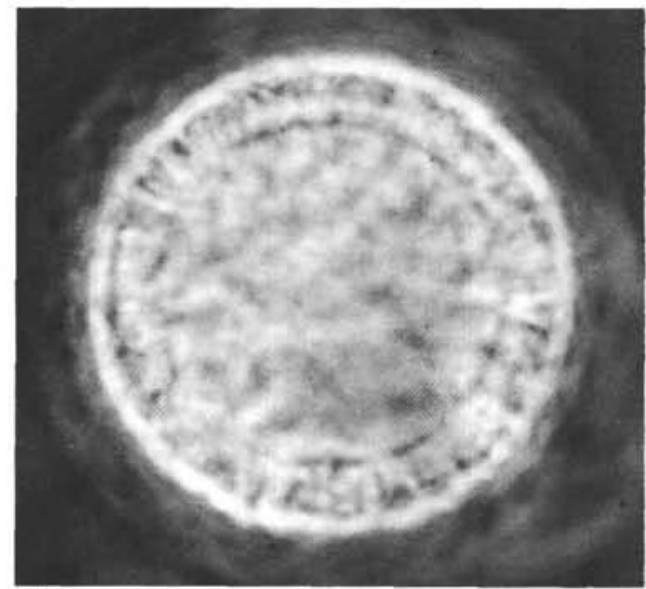

$4 a$

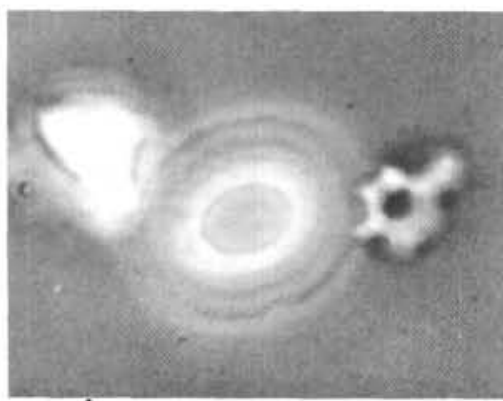

$5 a$

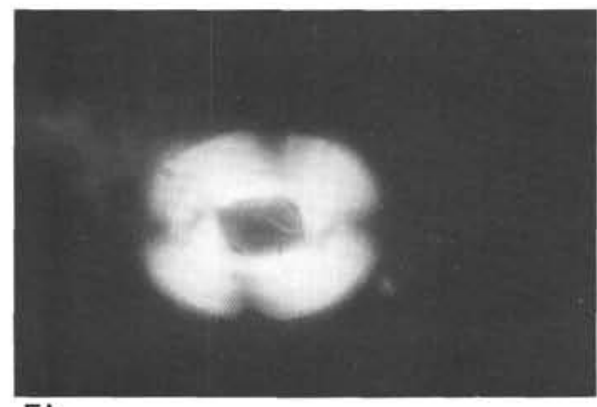

$5 b$

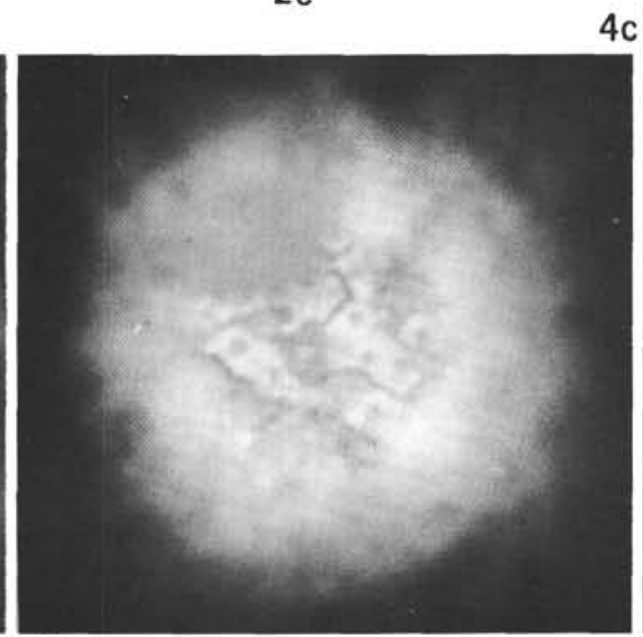

$4 \mathrm{~b}$

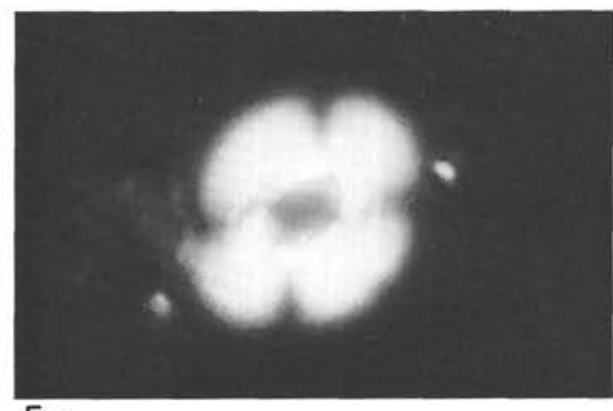

$5 c$ 
PLATE 4

All specimens approximately $\times 2800$.

Figure 1 Scyphosphaera apsteinii Lohmann. Side view. Sample 397-15-3, 40-41 cm.

1a. Phase contrast.

1b. Cross-polarized light.

Figure 2 Eiffellithus eximius (Stover). Distal side. Sample 397-4-4, 46-47 cm; reworked from Cretaceous.

2a. Phase contrast.

2b. Cross-polarized light.

2c. Cross-polarized light $+45^{\circ}$.

Figure 3 Discolithina japonica Takayama. Distal side. Sample 397-2-4, 80-81 cm.

3a. Phase contrast.

3b. Cross-polarized light.

3c. Cross-polarized light $+45^{\circ}$.

Figure 4 Eiffellithus turriseiffeli (Deflandre and Fert). Distal side. Sample 397-4-4, 46-47 cm; reworked from Cretaceous. Phase contrast.

Figure $5 \quad$ Parhabdolithus angustus (Stradner). Distal side. Sample 397-4-4, 46-47 cm; reworked from Cretaceous.

5a. Phase contrast.

5b. Cross-polarized light.

Figure 6 Gartnerago obliquum (Stradner). Distal side. Sample 397-4-4, 46-47 cm; reworked from Cretaceous.

6a. Phase contrast.

6b. Cross-polarized light.

6c. Cross-polarized light $+45^{\circ}$.

Figure 7 Lucianorhabdus maleformis Reinhardt. Side view. Sample 397-4-4, 46-47 cm; reworked from Cretaceous.

7a. Phase contrast.

7b. Cross-polarized light. 
PLATE 4

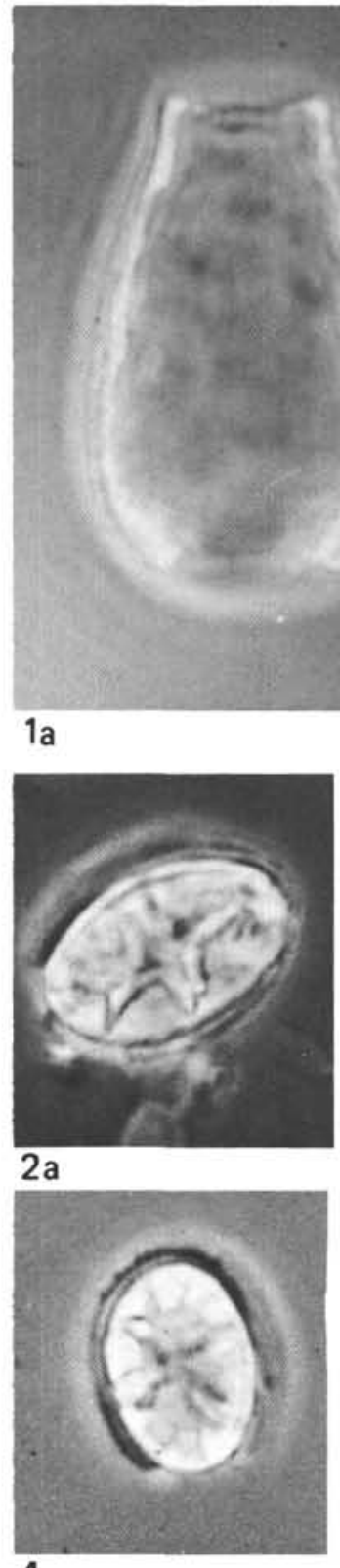

4

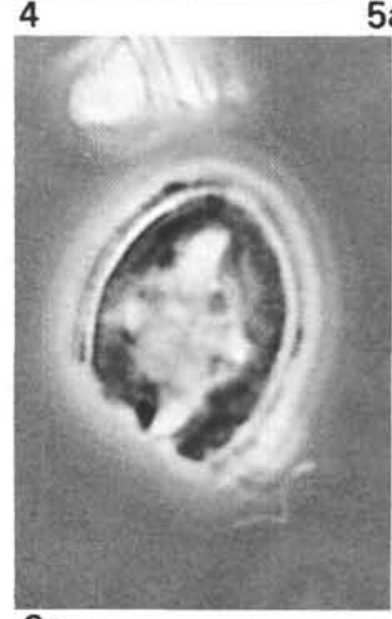

$6 a$

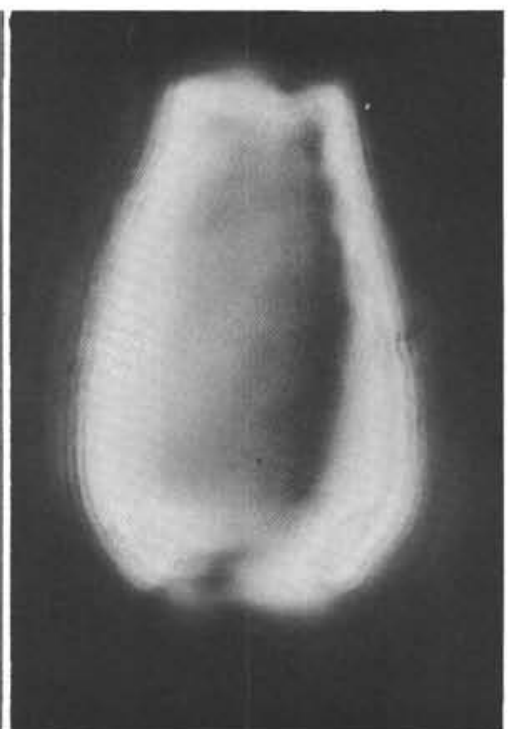

$1 \mathrm{~b}$
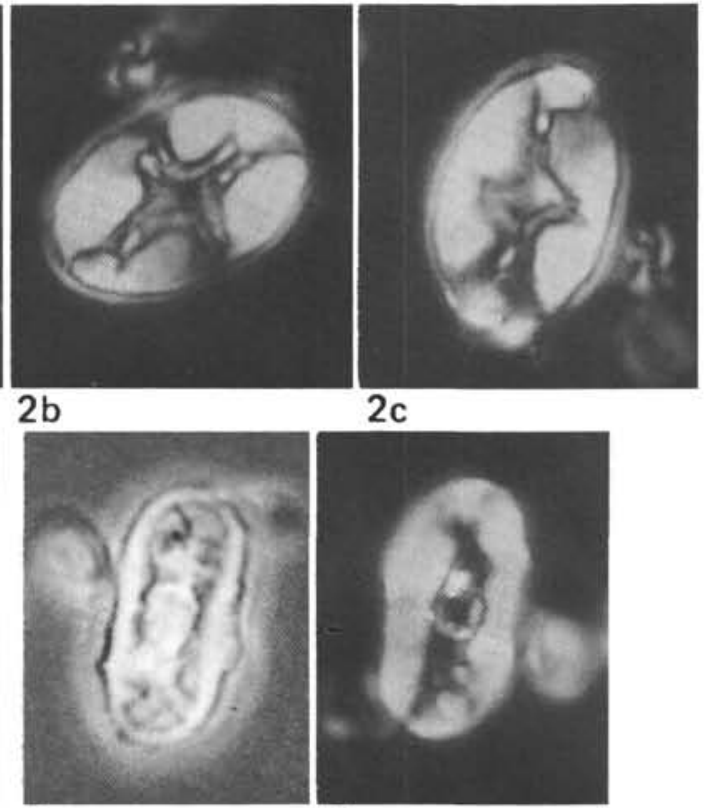

$5 a$
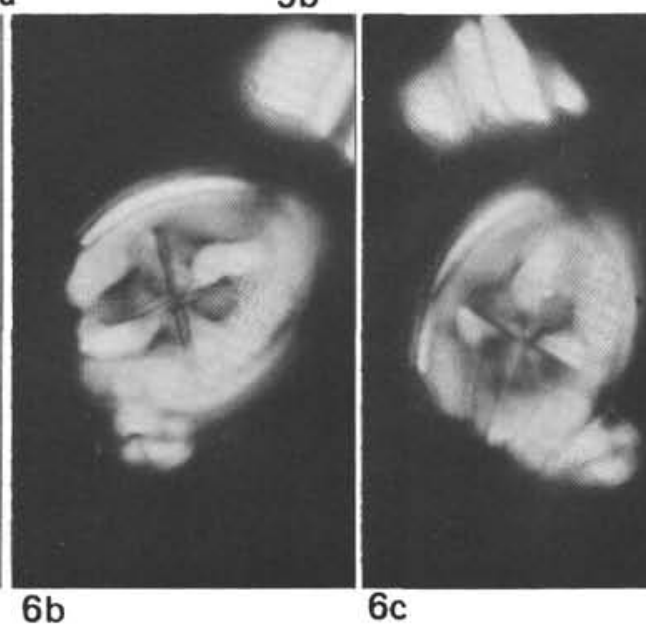

$6 c$

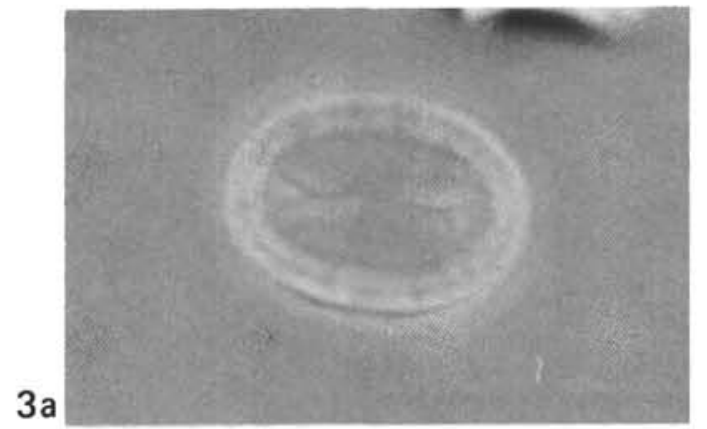

$3 a$

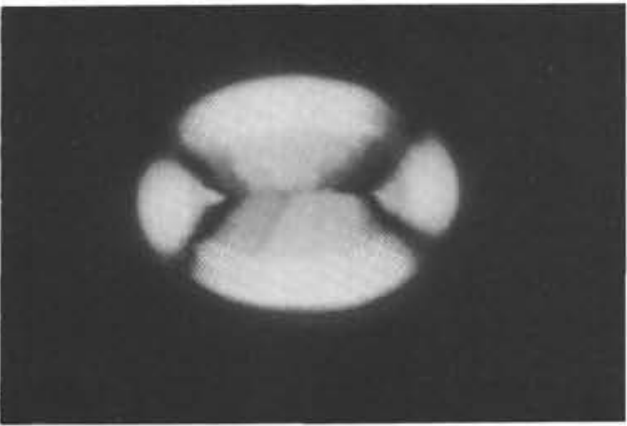

$3 b$
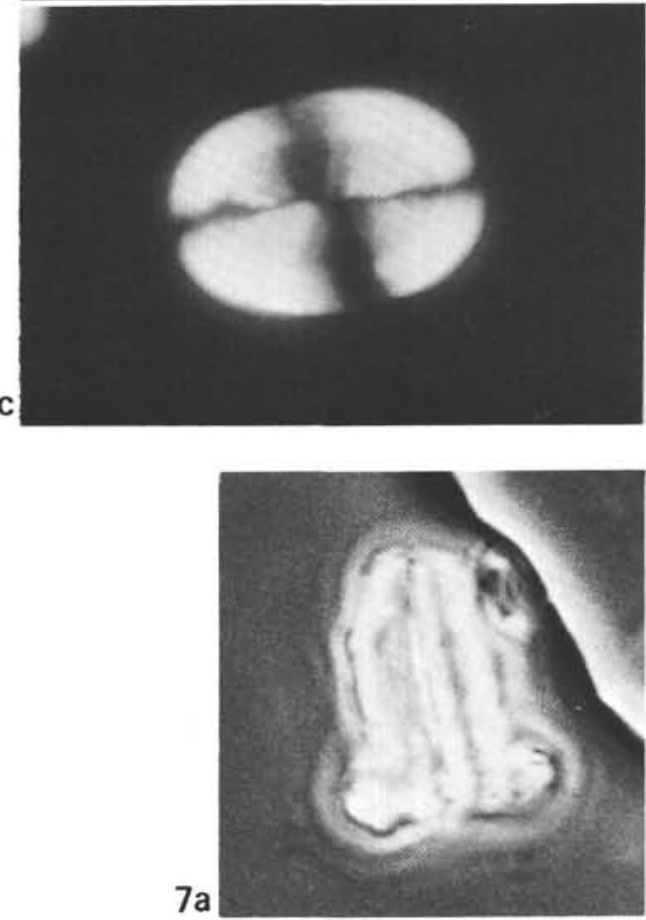

$7 a$

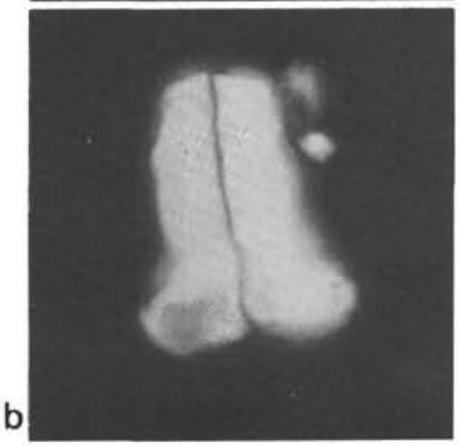




\section{PLATE 5}

All specimens scanning electron micrographs.

Figure 1 Emiliania huxleyi (Lohmann). Distal side. Sample $397-2-5,40-41 \mathrm{~cm}$.

Figure 2 Gephyrocapsa oceanica Kamptner. Distal side. Sample 397-1-1, 11-12 cm.

Figures 3, 6 Coccolithus cf. doronicoides Black and Barnes. Sample 397-2-6, 46-47 cm.

3. Distal side

6. Proximal side.

Figures 4, 5 Gephyrocapsa californiensis Kamptner. Distal side.

4. Sample 397-4-1, 40-41 cm.

5. Sample $397-2-2,40-41 \mathrm{~cm}$.

Figures 7-9 Cyclococcolithus cf. macintyrei Bukry and Bramlette. Sample 397-1-1, 11-12 cm.

7. Distal side.

8. Proximal side.

9. Side view.

Figure 10 Cyclococcolithus macintyrei Bukry and Bramlette. Distal side. Sample 397-1-1, 11-12 cm.

Figure 11 Reticulofenestra pseudoumbilica (Gartner). Distal side. Sample 397-23-5, 30-31 cm.

Figure 12 Pseudoemiliania lacunosa (Kamptner), Distal side. Sample 397-21-6, 40-41 cm. 
PLATE 5
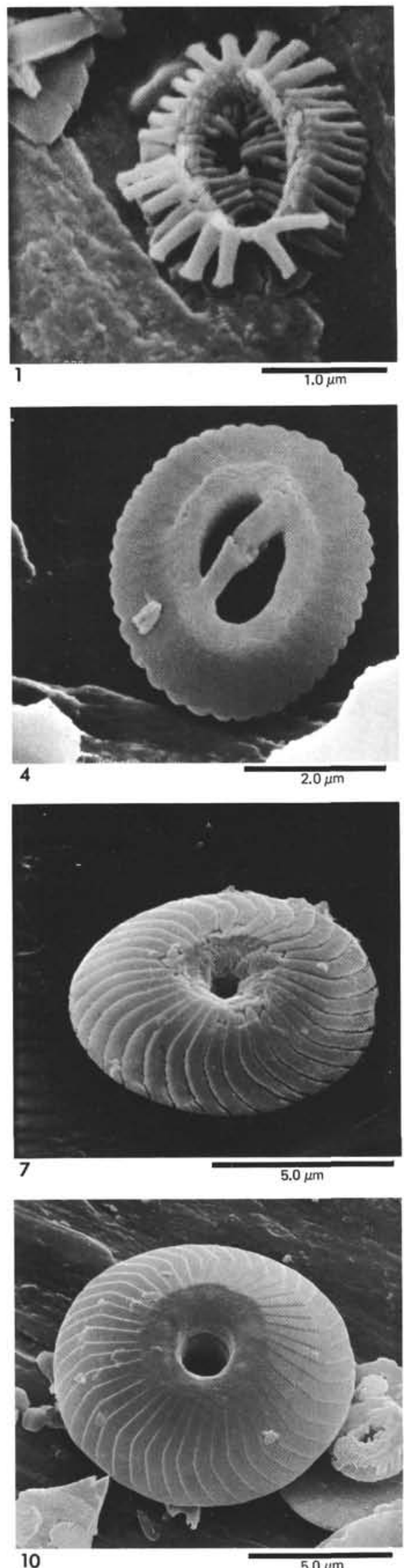
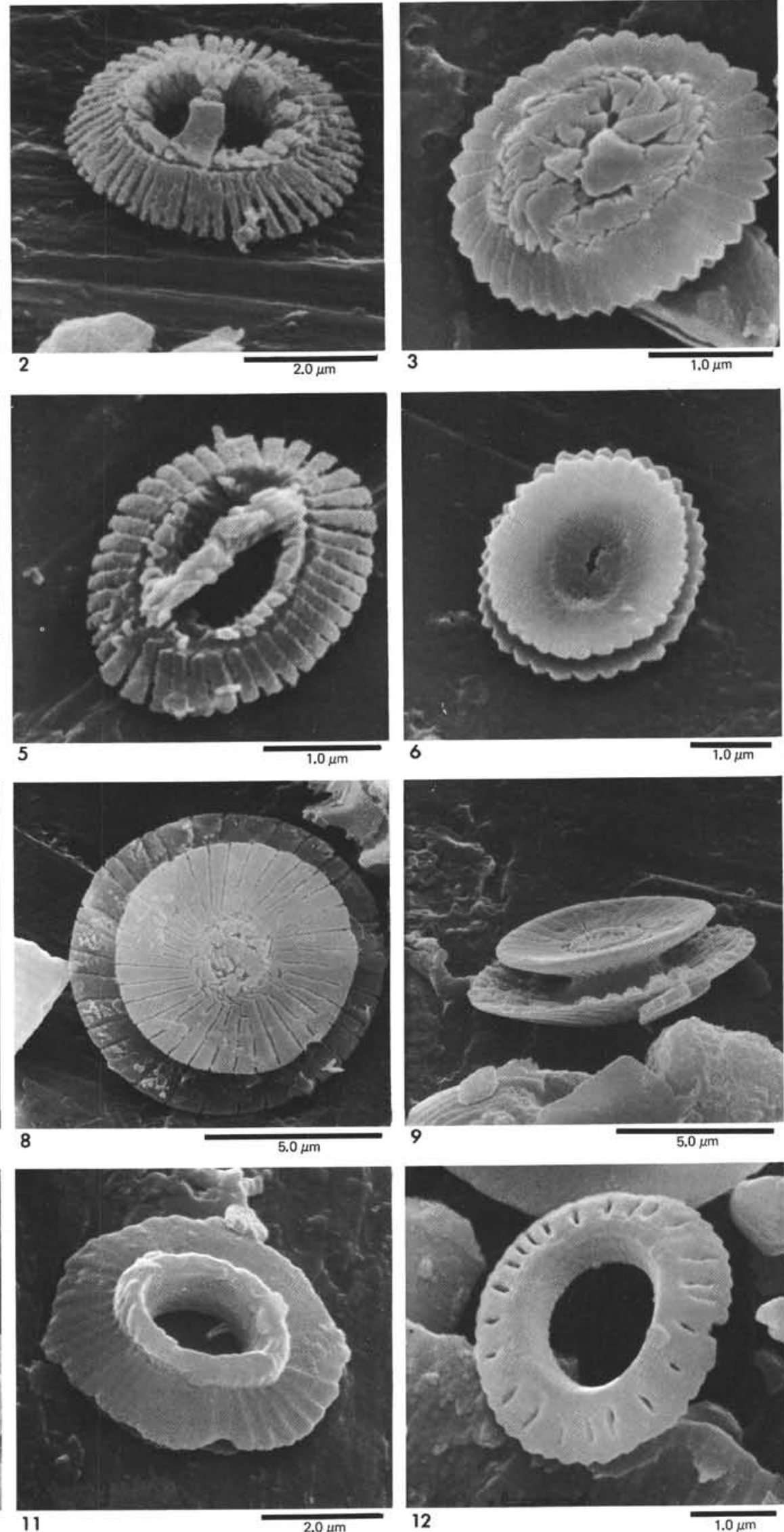
PLATE 6

All specimens scanning electron micrographs.

Figure 1 Ceratolithus cristatus Kamptner. Sample 397$23-5,30-31 \mathrm{~cm}$.

Figure 2 Syracosphaera pulchra Lohmann. Distal side. Sample 397-19, CC.

Figure $3 \quad$ Scyphosphaera apsteinii Lohmann. Side view. Sample 397-4-1, 40-41 cm.

Figures 4, 5 Discolithina discopora (Schiller). Sample 397$23-5,30-31 \mathrm{~cm}$.

4. Distal side.

5. Proximal side.

Figure 6 Discolithina japonica Takayama. Distal side. Sample 397-23-5, 30-31 cm.

Figure 7 Discolithina anisoternia Kamptner. Distal side. Sample 397-23-5, 30-31 cm.

Figure $8 \quad$ Umbilicosphaera mirabilis Lohmann. Proximal side. Sample 397-1-1, 11-12 cm.

Figures 9-12 Coccolithus pelagicus (Wallich).

9. Sample $397-2-6,46-47 \mathrm{~cm}$, proximal view.

10. Sample 397-21-6, 40-41 cm, distal side.

11. Sample 397-1-1, 11-12 cm, distal side.

12. Sample $397-2-6,46-47 \mathrm{~cm}$, proximal side. 
PLATE 6
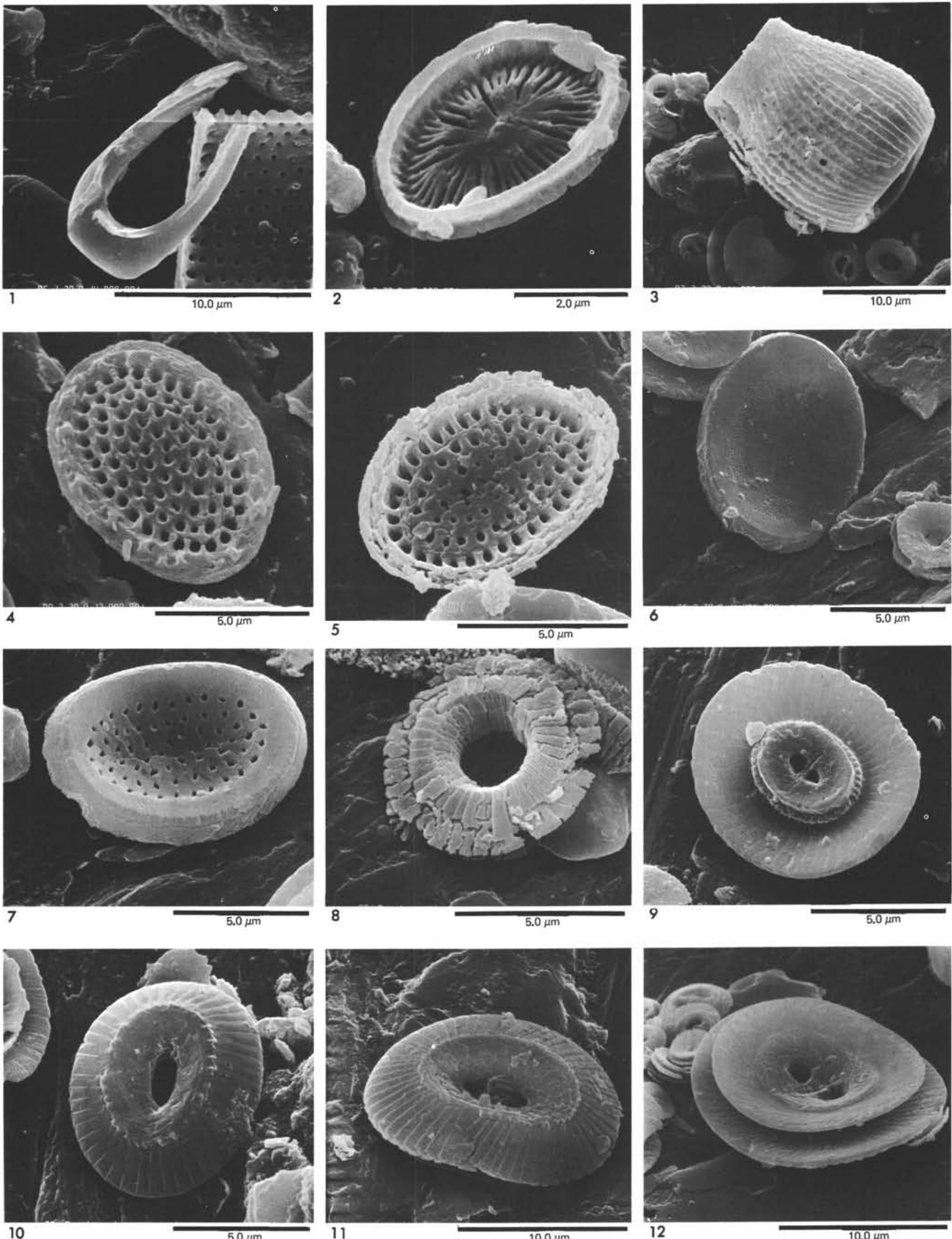


\section{PLATE 7}

All specimens scanning electron micrographs.

Figures 1, 2 Helicopontosphaera kamptneri Hay and Mohler. 1. Sample 397-4-1, 40-41 cm, proximal side. 2. Sample 397-1-1, 11-12 cm, distal side.

Figure 3 Helicopontosphaera sellii Bukry and Bramlette. Proximal side. Sample 397-23-5, 30-31 cm.

Figure 4 Discoaster sp. cf. brouweri Tan Sin Hok. Distal side. Sample 397-21-6, 40-41 cm.

Figures 5, 6 Discoaster surculus Martini and Bramlette. 5. Sample 397-21-6, 40-41 cm, distal side.

6. Sample 397-21-6, 40-41 cm, proximal side.

Figure 7 Discoaster pentaradiatus Tan Sin Hok. Proximal side. Sample 397-21-6, 40-41 cm.

Figure $8 \quad$ Rhabdosphaera clavigera Murray and Blackmann. Side View. Sample 397-4-1, 40-41 cm.

Figure 9 Aspidorhabdus stylifer (Lohmann). Side view. Sample 397-19, CC.

Figures 10, 11 Thoracosphaera heimi (Lohmann). Sample 397$1-1,11-12 \mathrm{~cm}$.

Figure 12 Lithastrinus floralis Stradner. Sample 397-4-1, 40-41 cm; reworked from Cretaceous. 
PLATE 7

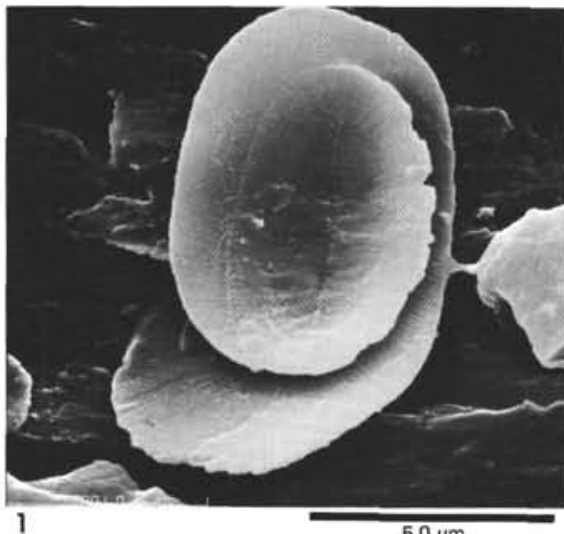

$5.0 \mu \mathrm{m}$
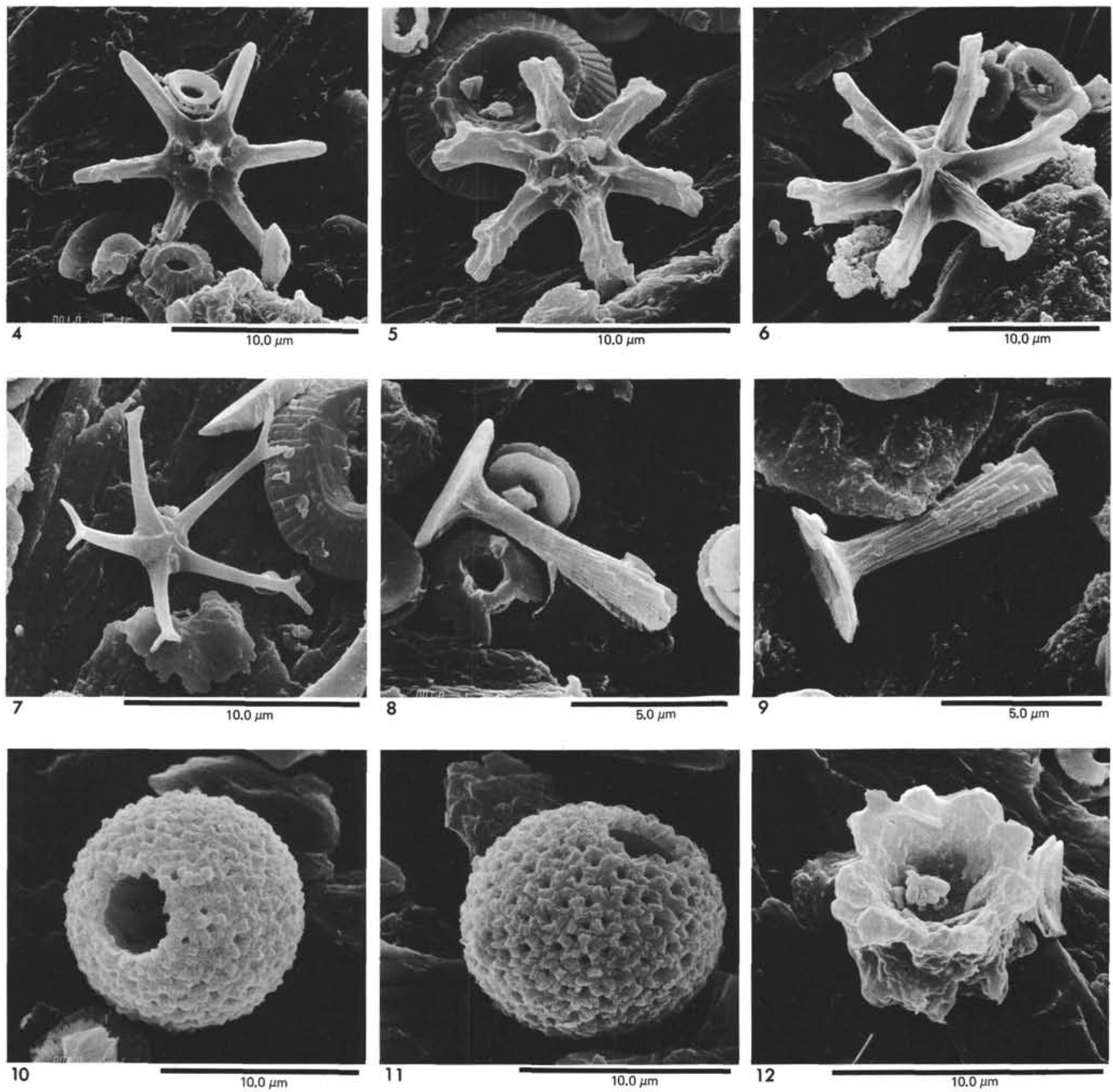